\title{
Favipiravir, lopinavir-ritonavir or combination therapy (FLARE): a randomised, double blind, $2 \times 2$ factorial placebo-controlled trial of early antiviral therapy in COVID-19
}

David M Lowe ${ }^{1,2}$, Li-An K Brown ${ }^{1}$, Kashfia Chowdhury ${ }^{3}$, Stephanie Davey ${ }^{4}$, Philip Yee ${ }^{4}$, Felicia $\mathrm{kkeji}^{3}$, Amalia Ndoutoumou ${ }^{3}$, Divya Shah ${ }^{5}$, Alexander Lennon ${ }^{5}$, Abhulya Rai ${ }^{5}$, Akosua A Agyeman ${ }^{6}$, Anna Checkley ${ }^{7}$, Nicola Longley ${ }^{7}$, Hakim-Moulay Dehbi $^{3}$, Nick Freemantle ${ }^{3}$, Judith Breuer $^{5,6 *}$, Joseph F Standing ${ }^{6,8 *}$, FLARE Investigators ${ }^{\dagger}$

1. Institute of Immunity and Transplantation, University College London, London, UK

2. Department of Clinical Immunology, Royal Free London NHS Foundation Trust, London, UK

3. Comprehensive Clinical Trials Unit, University College London, London, UK

4. Department of Rheumatology, Royal Free London NHS Foundation Trust, London, UK

5. Department of Virology, Great Ormond Street Hospital NHS Foundation Trust, London, UK

6. Infection, Immunity and Inflammation Research and Teaching Department, Institute of Child Health, University College London, London, UK

7. University College London Hospitals NHS Foundation Trust

8. Department of Pharmacy, Great Ormond Street Hospital NHS Foundation Trust, London, UK

* These authors contributed equally

${ }^{\dagger}$ See Supplementary Appendix for details

Corresponding author: Dr David M Lowe

UCL Institute of Immunity and Transplantation

Pears Building, Rowland Street

NW3 2PP

London, UK

d.lowe@ucl.ac.uk 


\section{Abstract}

2 Background: Early antiviral treatment is effective for COVID-19 but currently available agents are

3 expensive. Favipiravir is routinely used in many countries, but efficacy is unproven. Antiviral

4 combinations have not been systematically studied. We aimed to evaluate the effect of favipiravir,

5 lopinavir-ritonavir or the combination of both agents on SARS-CoV-2 viral load trajectory when

6 administered early.

Methods: We conducted a Phase 2, proof of principle, randomised, placebo-controlled, $2 \times 2$ factorial, double-blind trial of outpatients with early COVID-19 (within 7 days of symptom onset) at two sites

9 in the United Kingdom. Participants were randomised using a centralised online process to receive: favipiravir (1800mg twice daily on Day 1 followed by $400 \mathrm{mg}$ four times daily on Days 2-7) plus lopinavir-ritonavir $(400 \mathrm{mg} / 100 \mathrm{mg}$ twice daily on Day 1 , followed by $200 \mathrm{mg} / 50 \mathrm{mg}$ four times daily on Days 2-7); favipiravir plus lopinavir-ritonavir placebo; lopinavir-ritonavir plus favipiravir placebo; or both placebos. The primary outcome was SARS-CoV-2 viral load at Day 5, accounting for baseline viral load. ClinicalTrials.gov: NCT04499677.

Findings: Between 6 October 2020 and 4 November 2021, we recruited 240 participants. For the favipiravir+lopinavir-ritonavir, favipiravir+placebo, lopinavir-ritonavir+placebo and placebo-only arms, we recruited 61, 59, 60 and 60 participants and analysed 55, 56, 55 and 58 participants respectively who provided viral load measures at Day 1 and Day 5 . In the primary analysis, the mean viral load in the favipiravir+placebo arm had decreased by $0.57 \log _{10}(95 \% \mathrm{Cl}-1.21$ to $0.07, p=0.08)$ and in the lopinavir-ritonavir+placebo arm by $0.18 \log _{10}(95 \% \mathrm{Cl}-0.82$ to $0.46, \mathrm{p}=0.58)$ more than in the placebo arm at Day 5. There was no significant interaction between favipiravir and lopinavirritonavir (interaction coefficient term: $0.59 \log _{10}, 95 \% \mathrm{Cl}-0.32$ to $1.50, \mathrm{p}=0.20$ ). More participants had undetectable virus at Day 5 in the favipiravir+placebo arm compared to placebo only $(46.3 \%$ vs 
medRxiv preprint doi: https://doi.org/10.1101/2022.02.11.22270775; this version posted February 15, 2022. The copyright holder for this preprint

(which was not certified by peer review) is the author/funder, who has granted medRxiv a license to display the preprint in perpetuity.

It is made available under a CC-BY-NC-ND 4.0 International license.

$2426.9 \%$, odds ratio (OR): $2.47,95 \% \mathrm{Cl} 1.08$ to $5.65 ; \mathrm{p}=0.03$ ). Adverse events were observed more

25 frequently with lopinavir-ritonavir, mainly gastrointestinal disturbance. Favipiravir drug levels were

26 lower in the combination arm than the favipiravir monotherapy arm.

27 Interpretation: At the current doses, no treatment significantly reduced viral load in the primary

28 analysis. Favipiravir requires further evaluation with consideration of dose escalation. Lopinavir-

29 ritonavir administration was associated with lower plasma favipiravir concentrations.

30 Funding: LifeArc, UK. 


\section{Introduction}

33 Severe acute respiratory syndrome coronavirus 2 (SARS-CoV-2) continues to represent a major

34 threat to global health. Interrupting viral replication in early infection reduces the risk of COVID-19

35 disease progression and hospitalisation [1-4], and this is the most logical time to employ antiviral

36 medications. Efficacy has been demonstrated for neutralising monoclonal antibody treatments, but

37 these are vulnerable to loss of potency with new viral variants as observed with the B.1.1.529

38 (omicron) variant [5]. Furthermore, the cost of available oral antiviral and monoclonal treatments is

39 prohibitive for many countries.

40 A general principle of antiviral chemotherapy is that multiple agents with different modes of action

41 are often required, which can be particularly pertinent in the case of repurposed drugs where

42 antiviral potency using monotherapy may be limited. Combination therapy using a polymerase

43 inhibitor combined with a protease inhibitor, thereby targeting sequential steps in the viral

44 replication pathway, is a potential strategy [6]. Where SARS-CoV-1 was treated with the polymerase

45 inhibitor ribavirin in combination with the protease inhibitor lopinavir-ritonavir, and when this

46 combination was initiated immediately upon diagnosis, a significant decrease in mortality was seen

47 compared with historical controls [7]. Another study of this combination showed reduced mortality

48 and need for intubation when therapy was given early, but late rescue treatment had no effect [8].

49 Early post-exposure prophylaxis against Middle East Respiratory Syndrome (MERS-CoV) in healthcare

50 workers also showed that ribavirin plus lopinavir-ritonavir reduced the incidence of infection from

$5128 \%$ to $0 \%[9]$.

In early 2020 it was shown that whilst ribavirin had little effect on SARS-CoV-2 viral replication in

vitro, the orally available polymerase inhibitor favipiravir did have an in vitro potency within clinically

54 achievable range [10] [Supplementary Figure 1]. Whilst subsequent in vitro results have been less

55 promising, high-dose favipiravir achieving concentrations commensurate with human exposures

56 reduced viral load and lung histopathology in hamsters [11]. Early observational clinical studies 
reported benefits of favipiravir in COVID-19 patients $[12,13]$. Favipiravir generic formulations are

now in widespread use for COVID-19 in some regions of the world, but high-quality evidence on its

effect in early treatment is lacking. A recent pre-print suggested that favipiravir (as monotherapy

61 Whilst the HIV protease inhibitors tipranavir and nelfinavir showed higher in vitro potency against SARS-CoV-2 than lopinavir-ritonavir [10] safety concerns and limited clinical experience with both 


\section{Methods}

\section{Study design and participants}

81 FLARE was an early intervention trial testing the effect of oral antiviral therapy on viral load [19].

82 Participants received favipiravir plus lopinavir-ritonavir, favipiravir plus lopinavir-ritonavir placebo,

83 favipiravir placebo plus lopinavir-ritonavir, or placebos of both drugs. Favipiravir or matched placebo

84 was administered at a dose of $1800 \mathrm{mg}$ twice daily on Day 1 , followed by $400 \mathrm{mg}$ four times daily

85 from Day 2 to Day 7. Lopinavir-ritonavir or matched placebo were given at a dose of $400 \mathrm{mg} / 100 \mathrm{mg}$

86 twice daily on Day 1 , followed by $200 \mathrm{mg} / 50 \mathrm{mg}$ four times daily from Day 2 to Day 7 . Participants

87 were advised to take both Day 1 doses on the first day regardless of time of enrolment, due to the

88 perceived importance of achieving high antiviral levels as early as possible. Those recruited in the

89 afternoon took the first dose immediately and the second dose at least 6 hours later.

90 Participants aged between 18 and 70 years who had recently (within the last 5 days) developed

91 symptoms of COVID-19, who had tested positive for SARS-CoV-2 by PCR and were within 7 days of

92 symptom onset, or who were asymptomatic but had tested positive by PCR within the previous 48

93 hours, were eligible for the trial. Participants were ineligible if they had known hypersensitivity to

94 either drug or their ingredients/excipients, had chronic liver or kidney disease, were taking

95 concomitant medicines known to interact with the trial treatments, were being treated as a hospital

96 inpatient for any condition, were pregnant or breastfeeding or were participating in another

97 interventional clinical trial (treatment or vaccination). Before 8 June 2021, participants vaccinated against SARS-CoV-2 were excluded but this was reversed by the Trial Steering Committee due to the large number of vaccinated individuals presenting with infection at that time, and the importance of establishing whether early antiviral treatment is effective in a vaccinated population. Female participants of childbearing potential were required to provide a negative pregnancy test before 
measures during the trial; male participants with a female partner of childbearing potential were also required to use highly effective contraception.

Participants were informed about the trial via occupational health departments at participating

hospital sites and participant identification centres, via poster advertisements, social media or, from hospital sites and those in the local area from a list provided by NHS Digital.

Participants were recruited at two sites: Royal Free Hospital and University College London Hospital, both in London, UK.

The study was approved by the Wales Research Ethics Committee 3 (Ref: 20/WA/0210) and all participants provided written, informed consent.

\section{Randomisation and masking}

A pre-screening visit (usually by telephone) briefly assessed eligibility and collected the following information: study site, age ( $\leq 55$ vs $>55$ years), sex, height and weight (to calculate body mass index

(BMI)), symptomatic or asymptomatic, current smoking status (current or non-smoker/ex-smoker), 


\section{Procedures}

128 People willing to participate at pre-screening were visited in their home or seen in a designated

129 COVID-19 treatment area at recruitment sites. Following confirmation of eligibility and written informed consent, a nasopharyngeal swab (for participants who were symptomatic but had not tested positive) and baseline blood test was performed along with collection of clinical and demographic information. A pack containing trial medication, kits and instructions for collecting daily saliva samples (Saliva RNA Collection and Preservation devices, Norgen Biotek, Canada), a thermometer and participant diary was provided. The first saliva sample was taken followed by witnessed intake of the first dose of trial medication; participants were advised to take daily saliva samples each morning from Days 2 to 7 before eating, drinking or brushing teeth.

A telephone follow-up was performed on Day 5 and a second visit performed on Day 7 where saliva samples were collected and blood was drawn for safety and favipiravir pharmacokinetics. Stool samples were collected if provided. Follow up telephone calls or visits were made on Day 14; a pregnancy test was performed for women of childbearing potential and blood tests taken if abnormalities had been detected at Day 7. A final telephone call was made on Day 28.

\section{Outcomes}

The primary outcome was viral load measured by quantitative polymerase chain reaction (PCR) medication-related toxicity at Days 7 and 14, and proportion of participants admitted to hospital, intensive care or dead due to a COVID-19 related illness. outcomes of whole genome sequencing of SARS-CoV-2 and more extensive pharmacokineticpharmacodynamic modelling will be reported separately. 


\section{Laboratory analyses}

153 Full blood count, urea \& electrolytes, liver function tests and serum urate were measured in the diagnostic laboratory at Great Ormond Street Hospital (GOSH), London. Saliva viral load was also measured by the GOSH diagnostic laboratory. Samples with a cycle threshold $(\mathrm{Ct})$ value between 40 45 were repeated, and for the purposes of the primary analysis a viral load was calculated from the calibration curve if the repeat value was also $<45$. However, due to uncertainties in the

undetectable viral load, Ct values $>40$ were considered undetectable.

Serum antibody status at Day 1 and Day 7 was measured at the University of Birmingham via enzyme-linked immunosorbent assay, as described previously [20].

Favipiravir drug levels pre and post the second or third dose on Day 7 were measured in plasma by

The assay lower limit of quantification was $0.1 \mathrm{mg} / \mathrm{L}$.

\section{Statistical analysis}

It was assumed that a clinically significant difference in viral load between antiviral and placebo- 
medRxiv preprint doi: https://doi.org/10.1101/2022.02.11.22270775; this version posted February 15, 2022. The copyright holder for this preprint

(which was not certified by peer review) is the author/funder, who has granted medRxiv a license to display the preprint in perpetuity.

It is made available under a CC-BY-NC-ND 4.0 International license .

177

178

179

180

181

182

183

184

185

186

187

188

analysis was composed of all ITT participants for whom a measure of viral load was available at Day 1 and Day 5. Additionally, the primary outcome was analysed in a modified ITT (mITT) population, which excluded participants who had undetectable viral load both at Day 1 and Day 5 .

An analysis of covariance (ANCOVA) model was used to estimate the difference in viral load at 5 days post treatment between the treatment arms. The model included a term for each treatment (favipiravir active/placebo, and lopinavir-ritonavir active/placebo), an interaction term between the two treatments, and baseline viral load. Supportive analyses on the primary outcome included a model adjusting for (i) minimisation factors; (ii) minimisation factors, symptom duration and antibody status (post-hoc adjustment strategy); (iii) potential effect of the delta variant of the SARSCoV-2 virus, by adding a categorical variable reflecting the period of recruitment: no delta variant (before 24 April 2021), some delta variant (between 24 April 2021 and 12 June 2021) and predominantly delta variant period (post 12 June 2021). A linear mixed model was used to model the viral load trajectories from Day 1 to Day 7 between the four treatment arms. Two adjustment strategies were followed: (i) Day 2 to Day 7 viral loads were modelled as response variable, adjusted for Day 1 viral load; (ii) also adding minimisation factors, symptom duration and antibody status (post-hoc analysis). We used STATA/MP $17 \cdot 0$ for all analyses.

No interim analyses were planned and safety monitoring was undertaken by an Independent Data Monitoring Committee (IDMC). All participants provided written informed consent. The trial registration number was NCT04499677.

\section{Role of the Funder}

The funder of the study had no role in study design, data collection, data analysis, data interpretation, or writing of the report, but has reviewed this final report. 
medRxiv preprint doi: https://doi.org/10.1101/2022.02.11.22270775; this version posted February 15, 2022. The copyright holder for this preprint (which was not certified by peer review) is the author/funder, who has granted medRxiv a license to display the preprint in perpetuity.

It is made available under a CC-BY-NC-ND 4.0 International license .

200

201

202

203

204

205

206

207

208

\section{Results}

Between 6 October 2020 and 4 November 2021, we screened 1215 and recruited 240 participants

(Figure 1). Participant details are provided in Table 1 and minimisation factors in Table 2. Most

participants (90\%) were below the age of 55 years; $82 \%$ were Caucasian and $85 \%$ did not have any

comorbidities. $51 \%$ of those randomised were vaccinated against SARS-CoV-2, and the proportion of vaccinated participants was balanced across the four arms; $63 \%$ had detectable SARS-CoV-2 anti-

spike antibody at baseline. $66 \%$ of the participants started treatment within 5 days of symptom

onset. The time between symptom onset and start of treatment was similar between the arms.

As detailed in Figure 1, 13 participants withdrew from the trial and a further 28 discontinued

medication but provided samples for analysis. Predominantly this was due to toxicity which occurred disproportionately in arms including lopinavir-ritonavir (see Safety below). Overall 224 participants

(93.3\%) were included in the ITT analysis and 208 participants (86.7\%) in the $\mathrm{mITT}$ analysis of the primary outcome.

The primary outcome was SARS-CoV-2 viral load at Day 5 of therapy accounting for baseline viral load. Figure 2 and Table 3 present summary data for the entire ITT and mITT cohorts, while Supplementary Figure 2 displays results at participant level. In the primary analysis, there was no significant effect of any treatment arm on viral load: additional reduction in viral load versus placebo for favipiravir monotherapy $0.57 \log _{10}$ copies $/ \mathrm{mL}$ (95\% confidence interval (CI) -1.21 to $0.07, p=0.08$ ), for lopinavir-ritonavir monotherapy $0.18 \log _{10}$ copies $/ \mathrm{mL}(95 \% \mathrm{Cl}-0.82$ to $0.46, \mathrm{p}=0.58)$. There was no significant interaction between favipiravir and lopinavir-ritonavir but the coefficient was numerically in the direction of antagonism (interaction coefficient: $0.59 \log _{10}$ copies $/ \mathrm{mL}, 95 \% \mathrm{Cl}$ 0.32 to $1.50, p=0.20)$

For favipiravir monotherapy, we observed similar effect sizes after adjustment for minimisation factors or for a potential effect of the delta variant of SARS-CoV-2 ( $p=0.06)$. However, adjusting for the minimisation factors as well as symptom duration and antibody status, a stronger effect was 
noted $\left(-0.65 \log _{10}\right.$ copies $/ \mathrm{mL}[95 \% \mathrm{Cl}-1.23$ to -0.07$\left.], \mathrm{p}=0.03\right)$. Following the same adjustment

strategy and conditioning on baseline viral load, the mixed model analysis indicated a similar effect copies/mL [95\% Cl -1.17 to -0.08$]$, $\mathrm{p}=0.02$; Table 3).

The proportion of participants with undetectable viral load at Day 5 was somewhat higher in the favipiravir monotherapy arm (odds ratio of being undetectable 2.47 [95\% $\mathrm{Cl} 1.08$ to $5.65, \mathrm{p}=0.03]$ ) but there was no effect of other treatment arms (Table 4).

In post-hoc supportive analyses, we observed a significant interaction $(p=0.03)$ between treatment

We also analysed results according to pre-specified subgroups (vaccination status, antibody status observe any differences between treatments across subgroups (Table 5).

A total of 518 adverse events were reported in 191 (80\%) participants, of which 295 (57\%) events 
lopinavir-ritonavir (88\%) compared to those receiving favipiravir monotherapy $(46 \%)$ and placebo

251 (35\%). The odds of experiencing a related event were significantly higher in the lopinavir-ritonavir arm compared to placebo (OR 16.0 [95\% $\mathrm{Cl} 4.27$ to 60.0], $p<0.0001$ ). Specifically, the number of events of diarrhoea and nausea was higher in participants treated with lopinavir-ritonavir and combination therapy. As detailed above, more participants in arms containing lopinavir-ritonavir discontinued treatment. Adverse events are summarised in Supplementary Table 1.

We also measured liver function tests at Day 1 and Day 7 (Supplementary Table 2 and

As expected, serum uric acid levels significantly increased in the arms containing favipiravir (odds

There were three serious adverse events during the trial, all were hospitalisation due to progression arm) was admitted to intensive care. There were no deaths in the study. pre-dose and 30-60 minutes post-dose for measurement of favipiravir drug levels. Assays were run on samples from 31 participants in the favipiravir monotherapy arm and 28 participants in the combination arm. As shown in Figure 4, favipiravir levels at both trough and peak were significantly

273 lower in the combination treatment arm than in the favipiravir monotherapy arm. Of note, only a

274 minority of participants achieved levels close to the EC90. Supplementary Table 3 summarises 
medRxiv preprint doi: https://doi.org/10.1101/2022.02.11.22270775; this version posted February 15, 2022. The copyright holder for this preprint

(which was not certified by peer review) is the author/funder, who has granted medRxiv a license to display the preprint in perpetuity.

It is made available under a CC-BY-NC-ND 4.0 International license .

demographic data on this cohort of participants, which did not differ between the arms or from the

overall characteristics of the participants randomised to these arms.

277 There was no difference in duration of fever between the arms, which was only observed in a

278 minority of participants. There were also no differences between the arms in the proportion of

279 participants with positive anti-spike antibody by Day 7, quantitative antibody levels or the

280 magnitude of change from Day 1. 
medRxiv preprint doi: https://doi.org/10.1101/2022.02.11.22270775; this version posted February 15, 2022. The copyright holder for this preprint

(which was not certified by peer review) is the author/funder, who has granted medRxiv a license to display the preprint in perpetuity.

It is made available under a CC-BY-NC-ND 4.0 International license .

\section{Discussion}

283 When the FLARE trial was designed in March 2020, we identified the imperative to generate high-

284 quality Phase 2 proof of principle trial evidence on repurposed antivirals for early treatment of

285 COVID-19, and this question remains important. The trial opened for recruitment in September

2862020 , but proceeded predominantly at a single site as we did not receive research prioritisation in

287 the UK via Urgent Public Health (UPH) status.

Based on in vitro data and early clinical reports, favipiravir was chosen as the most promising orally available agent. Due to uncertainty whether favipiravir would be effective as monotherapy, the addition of lopinavir-ritonavir was proposed as an inexpensive, readily available protease inhibitor with evidence of some clinical effect against previous coronaviruses and modest in vitro anti-SARSCoV-2 activity. The major finding of FLARE is that, at the doses used, there is no clear evidence that either favipiravir monotherapy or favipiravir plus lopinavir-ritonavir produce clinically worthwhile reductions in viral load in early treatment. FLARE provides insufficient evidence to take favipiravir monotherapy or favipiravir plus lopinavir-ritonavir into Phase 3, and instead predicts that none of the intervention arms would provide important clinical benefit at the current dose. However, further study of favipiravir may be warranted. In particular, dose escalation studies might potentially identify more efficacious doses against SARS-CoV-2.

We found a numerically greater but non-significant reduction in viral load associated with favipiravir monotherapy in the primary analysis, while a post-hoc fully adjusted mixed model, similar to that used to report the effect of other antivirals [21], was modestly statistically significant at our prespecified threshold (Table 3, Figure 2). We also observed an increase in the proportion of patients with undetectable viral load compared to placebo, lopinavir-ritonavir or combination therapy (Table 
potential for antivirals to inhibit replication $[17,18]$. However, this may point towards efficacy in a group with the most potential to benefit.

Favipiravir is a ribosomal-dependent RNA polymerase ( $R d R p)$ inhibitor with a similar mode of action to molnupiravir. The magnitude of difference in viral load at Day 5 with favipiravir versus placebo in our trial (0.57 to $0.65 \log _{10}$ copies $/ \mathrm{mL}$, depending on analysis used) was similar to that seen with molnupiravir $\left(0.55 \log _{10}\right.$ copies $\left./ \mathrm{mL}\right)$ at the highest dose tested in trials ( $800 \mathrm{mg}$ twice daily) [21]: this clinical consequence.

We chose the favipiravir dose used in influenza trials of $3600 \mathrm{mg}$ on Day 1 followed by $1600 \mathrm{mg}$ daily thereafter because simulations using pharmacokinetic data provided by Fujifilm Toyama Chemical Co., Ltd suggested we should expect to achieve $90 \%$ viral replication inhibition (along with a slight advantage in higher pre-dose trough levels if the maintenance dose was split 4 times per day rather than twice per day [Supplementary Figure 1]). However, upon measuring favipiravir pharmacokinetics on Day 7, we found levels around one third of our pre-trial predictions and, perhaps more unexpectedly, significantly lower levels of favipiravir in the combination arm despite measurement being limited to those still taking IMP at this time point (Figure 4). time-dependent reductions in levels seen in Ebola [22], it was not clear that this would be the case with our dose regimen. However, pharmacokinetic data published after the start of FLARE indicate 
that favipiravir is likely to display time-dependent nonlinear pharmacokinetics at the doses used here [23], albeit intracellular concentrations with this dose regimen have been proposed to reach antiviral levels [24]. However, this time-dependent nonlinearity does not account for the lower levels seen in the combination compared with monotherapy arm. Whilst a cytochrome P450 mediated drug-drug interaction is not expected between favipiravir and lopinavir-ritonavir, possible explanations include lower favipiravir absorption associated with the gastrointestinal effects of lopinavir-ritonavir, or more unreported missed doses in the combination arm.

It remains possible that a concentration-dependent antiviral effect may nevertheless occur with the lower concentrations seen in FLARE, especially via mutagenesis. Viral sequencing work is ongoing to explore this possibility and a population pharmacokinetic-pharmacodynamic model is planned to investigate whether there is a concentration-response relationship with either viral load or mutagenesis. This model should identify the rationale for and doses to use in a future Phase 2 trial.

By including a placebo-controlled lopinavir-ritonavir monotherapy arm, FLARE has demonstrated that this agent has no potential to reduce viral load and is poorly tolerated particularly when treatment is first initiated. As such, FLARE provides a strong rationale not to take this drug into monotherapy. A similar design could have quickly ruled out other repurposed agents such as hydroxychloroquine.

An expected but problematic issue encountered with lopinavir-ritonavir was the frequency of side effects, especially gastrointestinal, leading to frequent discontinuation of treatment. We also encountered numerous potential drug-drug interactions, including with commonly prescribed medications such as budesonide and simvastatin, requiring exclusion of potential participants or modification/suspension of concomitant medications. These are important issues to consider with other ritonavir-boosted protease inhibitors (e.g. nirmatrelvir). 
355 As a result of the prolonged recruitment period for FLARE which coincided with the successful UK

vaccine roll-out, the Trial Steering Committee decided to include participants who had received a vaccine. Regardless of treatment arm, rate of viral load decay tended to be higher in participants who were vaccinated or antibody-positive at baseline.

Favipiravir is in routine usage for COVID-19 in many countries, but existing trial data are mixed. Some small, open-label studies have indicated benefits in terms of clinical outcomes [25-28] or viral shedding $[13,26]$. However, other studies have indicated no clinically important benefit [29, 30], including when given in early disease [31]. These studies were open label with heterogenous populations often including hospitalised patients, where antiviral treatment is expected to be less effective. Holubar et al performed a double-blind randomized trial of favipiravir in asymptomatic or mildly symptomatic adults within 72 hours of a positive SARS-CoV2 RT-PCR (median 5 days of symptoms) [14]. Among 116 patients, there was no difference in time to viral shedding cessation or symptom resolution. However, baseline $\mathrm{Ct}$ value (inversely related to viral load) tended to be lower while the change in $\mathrm{Ct}$ value between Days 1 to 7 tended to be greater in the favipiravir-treated arm.

Our study has some limitations. The recruited cohort was relatively young and healthy with lower viral loads than many reported elsewhere in the literature. We were unable to perform viral culture or infectivity assays which may have provided useful additional information. For logistical reasons, we were unable to obtain samples for pharmacokinetics on every participant in the study.

In conclusion, our results do not support routine usage or Phase 3 trials of favipiravir or lopinavirritonavir at the doses investigated. However, the results may indicate an effect of favipiravir when used for early treatment of COVID-19, especially in those with high baseline viral load, but further investigation is needed regarding dosing schedule or additive medication. Another relatively small study would be sufficient to establish this. We have conclusively demonstrated the ineffectiveness of lopinavir-ritonavir even in early disease and have identified a new drug interaction between 
medRxiv preprint doi: https://doi.org/10.1101/2022.02.11.22270775; this version posted February 15, 2022. The copyright holder for this preprint

(which was not certified by peer review) is the author/funder, who has granted medRxiv a license to display the preprint in perpetuity.

It is made available under a CC-BY-NC-ND 4.0 International license .

favipiravir and lopinavir-ritonavir with the latter apparently lowering plasma levels of the former.

These results have important implications for the global efforts against COVID-19.

\section{Contributions}

Conceptualisation: DML, H-MD, JB, NF, JFS. Formal analysis: KC, AAA, H-MD, NF, JFS. Funding acquisition: DML, JB, NF, JFS. Investigation: DML, LKB, SD, PY, DS, AL, AR, NL, AC. Methodology: DML, $\mathrm{H}-\mathrm{MD}, \mathrm{JB}, \mathrm{NF}$, JFS. Project administration: L-KB, FI, AN. Writing - original draft: DML, JFS. Writing review \& editing: all authors.

\section{Acknowledgements}

The authors would like to acknowledge: the Agile Lighthouse team within UKHSA for assistance with recruitment and Fujifilm Toyama Chemical Co. who provided favipiravir and favipiravir placebo free of charge. We also acknowledge Professor Chris Frost as a non-independent member of the Trial Steering Committee and Dr Mak Wenyao for intellectual contribution. The study was funded by LifeArc (COVID0005). JFS was funded by a UK Medical Research Council (MRC) fellowship (MR/M008665/) and AAA was supported by a MRC project grant (MR/W015560/1).

\section{Conflicts of interest}

DML has received personal fees from Gilead for an educational video on COVID-19 in immunodeficiency and from Merck for a roundtable discussion on risk of COVID-19 in immunosuppressed patients. DML also holds research grants from Blood Cancer UK, Bristol Myers Squibb and the British Society for Antimicrobial Chemotherapy, all outside the current work. NF has received funding from Gedeon Richter, Abbott Singapore, Galderma, ALK, AstraZeneca, Ipsen, Vertex, Novo Nordisk, Aimmune, Allergan and Novartis, all outside the current work. JB holds research funding from GSK, Wellcome Trust, UKRI, Rosetrees Foundation and the John Black Foundation, all outside the current work. All other authors declare no conflict of interest. 


\section{Figure legends}

Figure 1. CONSORT diagram for the FLARE trial. * SARS-CoV-2 vaccination was an exclusion in the earlier part of the trial.

Figure 2. Mean $\log _{10}$ SARS-CoV-2 viral load at baseline (Day 1) and Day 5 per treatment arm in (A) the full intention to treat (ITT) population and (B) the modified intention to treat (mITT) population, excluding participants with negative viral load at baseline and Day 5.

Figure 3. Mean $\log _{10}$ SARS-CoV-2 viral load at baseline (Day 1) and Day 5 per treatment arm in (A) participants with baseline viral load below or equal to the median level for the entire cohort and (B) participants with baseline viral load above the median level for the entire cohort.

Figure 4. Plasma favipiravir concentration in the combination favipiravir + lopinavir-ritonavir (LPV/r) arm and the favipiravir + placebo arm on Day 7 (A) pre-dose (trough) and (B) 30-60 minutes postdose (peak).

\section{Supplementary Figure legends}

Supplementary Figure 1. Pharmacometric modelling of predicted plasma concentrations for favipiravir and lopinavir-ritonavir at the doses used in the FLARE trial, presented in relation to the half maximal effective concentration (EC50) and 90\% maximal effective concentration (EC90). Simulations are presented for a twice daily (BD) dosing regime and four times daily (QDS) dosing regime.

Supplementary Figure 2. $\log _{10}$ SARS-CoV-2 viral load at baseline (Day 1 ) and Day 5 presented per participant for (A) favipiravir + lopinavir-ritonavir (LPV/r), (B) favipiravir + placebo, (C) LPV/r + placebo and (D) placebo only.

Supplementary Figure 3. Mean $\log _{10}$ SARS-CoV-2 viral load per treatment arm on each day of treatment in $(A)$ the entire cohort, $(B)$ participants with baseline viral load below or equal to the median level and (C) participants with baseline viral load above the median level.

Supplementary Figure 4. Proportion of participants with detectable viral load at baseline who had undetectable viral load ( $\mathrm{C} t \geq 40$ ) on each subsequent day of treatment, per treatment arm.

Underlying data are presented in the accompanying table.

Supplementary Figure 5. Mean $\log _{10}$ SARS-CoV-2 viral load per treatment arm on each day of treatment and per study arm presented (A) according to vaccination status and $(B)$ according to baseline antibody status.

Supplementary Figure 6. (A) Serum alanine aminotransferase (ALT) concentration, (B) serum aspartate aminotransferase (AST) concentration and (C) serum uric acid concentration at Day 1 , Day 7 and Day 14 according to treatment arm. Blood tests were usually only taken at Day 14 if abnormal at Day 7. 


\section{References}

1. Gupta A, Gonzalez-Rojas Y, Juarez E, Crespo Casal M, Moya J, Falci DR, et al. Early Treatment for Covid-19 with SARS-CoV-2 Neutralizing Antibody Sotrovimab. N Engl J Med

2021,385:1941-1950.

2. Jayk Bernal A, Gomes da Silva MM, Musungaie DB, Kovalchuk E, Gonzalez A, Delos Reyes V, et al. Molnupiravir for Oral Treatment of Covid-19 in Nonhospitalized Patients. N Eng/ J Med 2021.

3. Weinreich DM, Sivapalasingam S, Norton T, Ali S, Gao H, Bhore R, et al. REGN-COV2, a Neutralizing Antibody Cocktail, in Outpatients with Covid-19. N Engl J Med 2021,384:238251.

4. Owen DR, Allerton CMN, Anderson AS, Aschenbrenner L, Avery M, Berritt S, et al. An oral SARS-CoV-2 M(pro) inhibitor clinical candidate for the treatment of COVID-19. Science 2021,374:1586-1593.

5. Syed AM, Ciling A, Khalid MM, Sreekumar B, Chen PY, Kumar GR, et al. Omicron mutations enhance infectivity and reduce antibody neutralization of SARS-CoV-2 virus-like particles. medRxiv 2022.

6. Sanders JM, Monogue ML, Jodlowski TZ, Cutrell JB. Pharmacologic Treatments for Coronavirus Disease 2019 (COVID-19): A Review. JAMA 2020,323:1824-1836.

7. Chu CM, Cheng VC, Hung IF, Wong MM, Chan KH, Chan KS, et al. Role of lopinavir/ritonavir in the treatment of SARS: initial virological and clinical findings. Thorax 2004,59:252-256.

8. Chan KS, Lai ST, Chu CM, Tsui E, Tam CY, Wong MM, et al. Treatment of severe acute respiratory syndrome with lopinavir/ritonavir: a multicentre retrospective matched cohort study. Hong Kong Med J 2003,9:399-406.

9. Park SY, Lee JS, Son JS, Ko JH, Peck KR, Jung Y, et al. Post-exposure prophylaxis for Middle East respiratory syndrome in healthcare workers. J Hosp Infect 2019,101:42-46.

10. Arshad U, Pertinez H, Box H, Tatham L, Rajoli RKR, Curley P, et al. Prioritization of Anti-SARSCov-2 Drug Repurposing Opportunities Based on Plasma and Target Site Concentrations Derived from their Established Human Pharmacokinetics. Clin Pharmacol Ther 2020,108:775790.

11. Kaptein SJF, Jacobs S, Langendries L, Seldeslachts L, Ter Horst S, Liesenborghs L, et al. Favipiravir at high doses has potent antiviral activity in SARS-CoV-2-infected hamsters, whereas hydroxychloroquine lacks activity. Proc Natl Acad Sci U S A 2020,117:26955-26965.

12. Cai Q, Yang M, Liu D, Chen J, Shu D, Xia J, et al. Experimental Treatment with Favipiravir for COVID-19: An Open-Label Control Study. Engineering (Beijing) 2020,6:1192-1198. 
13. Ivashchenko AA, Dmitriev KA, Vostokova NV, Azarova VN, Blinow AA, Egorova AN, et al. AVIFAVIR for Treatment of Patients With Moderate Coronavirus Disease 2019 (COVID-19): Interim Results of a Phase II/III Multicenter Randomized Clinical Trial. Clin Infect Dis 2021,73:531-534.

14. Holubar A SA, Purington N, Hedlin H, Bunning B, Walter KS, Bonilla H, Boumis A, Chen M, Clinton K, Dewhurst L, Epstein C, Jagannathan P, Kaszynski RH, Panu L, Parsonnet J, Ponder EL, Quintero O, Sefton E, Singh U, Soberanis L, Truong H, Andrews JR, Desai M, Khosla C, Maldonado Y. Favipiravir for treatment of outpatients with asymptomatic or uncomplicated COVID-19: a double-blind randomized, placebo-controlled, phase 2 trial. medRxiv 2021.11.22.21266690.

15. Ader F, Peiffer-Smadja N, Poissy J, Bouscambert-Duchamp M, Belhadi D, Diallo A, et al. An open-label randomized controlled trial of the effect of lopinavir/ritonavir, lopinavir/ritonavir plus IFN- $\beta-1 \mathrm{a}$ and hydroxychloroquine in hospitalized patients with COVID-19. Clin Microbiol Infect 2021,27:1826-1837.

16. Lopinavir-ritonavir in patients admitted to hospital with COVID-19 (RECOVERY): a randomised, controlled, open-label, platform trial. Lancet 2020,396:1345-1352.

17. Gonçalves A, Bertrand J, Ke R, Comets E, de Lamballerie X, Malvy D, et al. Timing of Antiviral Treatment Initiation is Critical to Reduce SARS-CoV-2 Viral Load. CPT Pharmacometrics Syst Pharmacol 2020,9:509-514.

18. Gastine S, Pang J, Boshier FAT, Carter SJ, Lonsdale DO, Cortina-Borja M, et al. Systematic Review and Patient-Level Meta-Analysis of SARS-CoV-2 Viral Dynamics to Model Response to Antiviral Therapies. Clin Pharmacol Ther 2021,110:321-333.

19. Brown LK, Freemantle N, Breuer J, Dehbi HM, Chowdhury K, Jones G, et al. Early antiviral treatment in outpatients with COVID-19 (FLARE): a structured summary of a study protocol for a randomised controlled trial. Trials 2021; 22:193

20. Cook AM, Faustini SE, Williams $U$, Cunningham AF, Drayson MT, Shields AM, et al. Validation of a combined ELISA to detect IgG, IgA and IgM antibody responses to SARS-CoV-2 in mild or moderate non-hospitalised patients. J Immunol Methods 2021,494:113046.

21. Fischer WA, 2nd, Eron JJ, Jr., Holman W, Cohen MS, Fang L, Szewczyk L, et al. A Phase 2a clinical trial of Molnupiravir in patients with COVID-19 shows accelerated SARS-CoV-2 RNA clearance and elimination of infectious virus. Sci Trans/ Med 2021:eabl7430.

22. Nguyen TH, Guedj J, Anglaret X, Laouenan C, Madelain V, Taburet AM, et al. Favipiravir pharmacokinetics in Ebola-Infected patients of the JIKI trial reveals concentrations lower than targeted. PLoS Neg/ Trop Dis 2017,11:e0005389.

23. Wang $\mathrm{Y}$, Zhong W, Salam A, Tarning J, Zhan Q, Huang JA, et al. Phase 2a, open-label, doseescalating, multi-center pharmacokinetic study of favipiravir (T-705) in combination with oseltamivir in patients with severe influenza. EBioMedicine 2020,62:103125.

24. Pertinez $\mathrm{H}$, Rajoli RKR, Khoo $\mathrm{SH}$, Owen A. Pharmacokinetic modelling to estimate intracellular favipiravir rib ofuranosyl-5'-triphosphate exposure to support posology for SARSCoV-2. J Antimicrob Chemother 2021,76:2121-2128. 
medRxiv preprint doi: https://doi.org/10.1101/2022.02.11.22270775; this version posted February 15, 2022. The copyright holder for this preprint

(which was not certified by peer review) is the author/funder, who has granted medRxiv a license to display the preprint in perpetuity.

It is made available under a CC-BY-NC-ND 4.0 International license .

25. Shinkai M, Tsushima K, Tanaka S, Hagiwara E, Tarumoto N, Kawada I, et al. Efficacy and Safety of Favipiravir in Moderate COVID-19 Pneumonia Patients without Oxygen Therapy: A Randomized, Phase III Clinical Trial. Infect Dis Ther 2021,10:2489-2509.

26. Ruzhentsova TA, Oseshnyuk RA, Soluyanova TN, Dmitrikova EP, Mustafaev DM, Pokrovskiy $\mathrm{KA}$, et al. Phase 3 trial of coronavir (favipiravir) in patients with mild to moderate COVID-19. Am J Transl Res 2021,13:12575-12587.

27. Udwadia ZF, Singh P, Barkate H, Patil S, Rangwala S, Pendse A, et al. Efficacy and safety of favipiravir, an oral RNA-dependent RNA polymerase inhibitor, in mild-to-moderate COVID19: A randomized, comparative, open-label, multicenter, phase 3 clinical trial. Int J Infect Dis 2021,103:62-71.

28. Doi $Y$, Hibino $M$, Hase $R$, Yamamoto $M$, Kasamatsu $Y$, Hirose $M$, et al. A Prospective, Randomized, Open-Label Trial of Early versus Late Favipiravir Therapy in Hospitalized Patients with COVID-19. Antimicrob Agents Chemother 2020,64.

29. Khamis F, Al Naabi H, Al Lawati A, Ambusaidi Z, Al Sharji M, Al Barwani U, et al. Randomized controlled open label trial on the use of favipiravir combined with inhaled interferon beta- $1 \mathrm{~b}$ in hospitalized patients with moderate to severe COVID-19 pneumonia. Int J Infect Dis 2021,102:538-543.

30. Solaymani-Dodaran M, Ghanei M, Bagheri M, Qazvini A, Vahedi E, Hassan Saadat S, et al. Safety and efficacy of Favipiravir in moderate to severe SARS-CoV-2 pneumonia. Int Immunopharmacol 2021,95:107522.

31. Chuah CH, Chow TS, Hor CP, Cheng JT, Ker HB, Lee HG, et al. Efficacy of Early Treatment with Favipiravir on Disease Progression among High Risk COVID-19 Patients: A Randomized, Open-Label Clinical Trial. Clin Infect Dis 2021. 
Table 1. Participant baseline characteristics

\begin{tabular}{|c|c|c|c|c|c|c|}
\hline Characteristics at screening & & Favipiravir+LPV/r (N=61) & $\begin{array}{l}\text { Favipiravir+Placebo } \\
(\mathrm{N}=59)\end{array}$ & $\mathrm{LPV} / \mathrm{r}+\mathrm{Placebo}(\mathrm{N}=60)$ & $\begin{array}{l}\text { Placebo } \\
(\mathrm{N}=60)\end{array}$ & $\begin{array}{l}\text { Total } \\
(\mathrm{N}=240)\end{array}$ \\
\hline Age (years) & mean $(s d)$ & $40.3(13.1)$ & $40.3(12.1)$ & $38.6(11.5)$ & $40.6(12.2)$ & $40.0(12.2)$ \\
\hline Height $(\mathrm{cm})$ & mean (sd) & $172.8(9.1)$ & $172.5(9.6)$ & $172.1(9.7)$ & $171.2(9.7)$ & $172.2(9.5)$ \\
\hline Weight (kg) & mean $(s d)$ & $76.0(17.0)$ & $76.5(14.1)$ & $74.8(16.6)$ & 75.4 (15.9) & 75.7 (15.9) \\
\hline Pulse Rate (bpm) & mean $(\mathrm{sd})$ & $72.6(11.4)$ & $72.6(11.1)$ & $76.9(10.5)$ & $75.2(10.9)$ & $74.3(11.1)$ \\
\hline Respiratory Rate (bpm) & mean (sd) & $16.9(3.5)$ & $16.5(2.6)$ & $16.6(2.7)$ & $16.8(2.8)$ & $16.7(2.9)$ \\
\hline Body Temperature $\left({ }^{\circ} \mathrm{C}\right)$ & mean $(\mathrm{sd})$ & $36.8(0.7)$ & $36.7(0.6)$ & $36.8(0.7)$ & $36.6(0.6)$ & $36.7(0.6)$ \\
\hline HIV status & $\mathrm{N}(\%)$ & & & & & \\
\hline Positive & & $1(1.6)$ & $0(0.0)$ & $0(0.0)$ & $0(0.0)$ & $1(0.4)$ \\
\hline Negative & & $17(27.9)$ & $22(37.3)$ & $20(33.3)$ & $19(31.7)$ & $78(32.5)$ \\
\hline Unknown & & $43(70.5)$ & $37(62.7)$ & $40(66.7)$ & $41(68.3)$ & $161(67.1)$ \\
\hline Vaccinated & $\mathrm{N}(\%)$ & & & & & \\
\hline Yes & & $32(52.5)$ & $30(50.8)$ & $31(51.7)$ & $30(50.0)$ & $123(51.2)$ \\
\hline No & & $29(47.5)$ & $29(49.2)$ & $29(48.3)$ & $30(50.0)$ & $117(48.8)$ \\
\hline Type of vaccine & $\mathrm{N}(\%)$ & & & & & \\
\hline Pfizer/BioNTech & & $14(23.0)$ & $13(22.0)$ & $19(31.7)$ & $8(13.3)$ & $54(22.5)$ \\
\hline Oxford/AstraZeneca & & $16(26.2)$ & $17(28.8)$ & $12(20.0)$ & $21(35.0)$ & $66(27.5)$ \\
\hline
\end{tabular}




\begin{tabular}{|c|c|c|c|c|c|c|}
\hline Moderna & & $2(3.3)$ & $0(0.0)$ & $0(0.0)$ & $1(1.7)$ & $3(1.3)$ \\
\hline Number of doses & $\mathrm{N}(\%)$ & & & & & \\
\hline One & & $7(11.5)$ & $5(8.5)$ & $7(11.7)$ & $3(5.0)$ & $22(9.2)$ \\
\hline Two & & $24(39.3)$ & $25(42.4)$ & $24(40.0)$ & $27(45.0)$ & $100(41.7)$ \\
\hline Three & & $1(1.6)$ & $0(0.0)$ & $0(0.0)$ & $0(0.0)$ & $1(0.4)$ \\
\hline Symptom onset & $\mathrm{N}(\%)$ & & & & & \\
\hline$\leq 5$ days & & $43(70.5)$ & $39(66.1)$ & $38(63.3)$ & $37(62.7)$ & $157(65.7)$ \\
\hline$>5$ days & & $18(29.5)$ & $20(33.9)$ & $22(36.7)$ & $22(37.3)$ & $82(34.3)$ \\
\hline SARS-CoV-2 antibody status & $\mathrm{N}(\%)$ & & & & & \\
\hline Negative & & $21(34.4)$ & $21(36.2)$ & $23(38.3)$ & $23(38.3)$ & $88(36.8)$ \\
\hline Positive & & $40(65.6)$ & $37(63.8)$ & 37 (61.7) & $37(61.7)$ & $151(63.2)$ \\
\hline
\end{tabular}

LPV/r: lopinavir-ritonavir, bpm: beats per minute. 
Table 2. Participant minimisation factors.

\begin{tabular}{|c|c|c|c|c|c|}
\hline $\begin{array}{l}\text { Minimisation factors } \\
\mathrm{N}(\%)\end{array}$ & $\begin{array}{l}\text { Favipiravir+LPV/r } \\
(\mathrm{N}=61)\end{array}$ & $\begin{array}{l}\text { Favipiravir+Placebo } \\
(\mathrm{N}=59)\end{array}$ & $\begin{array}{l}\text { LPV/r+Placebo } \\
(\mathrm{N}=60)\end{array}$ & $\begin{array}{l}\text { Placebo } \\
(\mathrm{N}=60)\end{array}$ & $\begin{array}{l}\text { Total } \\
(\mathrm{N}=240)\end{array}$ \\
\hline \multicolumn{6}{|l|}{ Site } \\
\hline Royal Free & $56(91.8)$ & $55(93.2)$ & 55 (91.7) & $55(91.7)$ & $221(92.1)$ \\
\hline UCLH & $5(8.2)$ & $4(6.8)$ & $5(8.3)$ & $5(8.3)$ & $19(7.9)$ \\
\hline \multicolumn{6}{|l|}{ Age (years) } \\
\hline$\leq 55$ & $53(86.9)$ & $52(88.1)$ & 55 (91.7) & 55 (91.7) & $215(89.6)$ \\
\hline$>55$ & 8 (13.1) & 7 (11.9) & $5(8.3)$ & $5(8.3)$ & $25(10.4)$ \\
\hline \multicolumn{6}{|l|}{ Gender } \\
\hline Male & $31(50.8)$ & $32(54.2)$ & $29(48.3)$ & 31 (51.7) & $123(51.2)$ \\
\hline Female & $30(49.2)$ & $27(45.8)$ & 31 (51.7) & $29(48.3)$ & $117(48.8)$ \\
\hline \multicolumn{6}{|l|}{ Ethnicity } \\
\hline Caucasian & $50(82.0)$ & $49(83.1)$ & $49(81.7)$ & $49(81.7)$ & $197(82.1)$ \\
\hline Other & $11(18.0)$ & $10(16.9)$ & $11(18.3)$ & $11(18.3)$ & 43 (17.9) \\
\hline \multicolumn{6}{|l|}{$\mathrm{BMI}\left(\mathrm{kg} / \mathrm{m}^{2}\right)$} \\
\hline$<30$ & $51(83.6)$ & $49(83.1)$ & $50(83.3)$ & $50(83.3)$ & $200(83.3)$ \\
\hline$\geq 30$ & $10(16.4)$ & 10 (16.9) & $10(16.7)$ & $10(16.7)$ & $40(16.7)$ \\
\hline Symptomatic disease & & & & & \\
\hline
\end{tabular}




\begin{tabular}{|c|c|c|c|c|c|}
\hline Yes & $61(100.0)$ & $59(100.0)$ & $60(100.0)$ & $59(98.3)$ & 239 (99.6) \\
\hline No & $0(0.0)$ & $0(0.0)$ & $0(0.0)$ & $1(1.7)$ & $1(0.4)$ \\
\hline \multicolumn{6}{|c|}{ Current smoker } \\
\hline Yes & $6(9.8)$ & $7(11.9)$ & $7(11.7)$ & $7(11.7)$ & $27(11.3)$ \\
\hline No & $55(90.2)$ & $52(88.1)$ & $53(88.3)$ & $53(88.3)$ & $213(88.8)$ \\
\hline \multicolumn{6}{|c|}{ Vaccinated } \\
\hline Yes & $32(52.5)$ & $30(50.8)$ & $31(51.7)$ & $30(50.0)$ & $123(51.2)$ \\
\hline No & $29(47.5)$ & $29(49.2)$ & $29(48.3)$ & $30(50.0)$ & $117(48.8)$ \\
\hline \multicolumn{6}{|c|}{ Comorbidity } \\
\hline Present & $11(18.0)$ & $9(15.3)$ & $8(13.3)$ & $8(13.3)$ & $36(15.0)$ \\
\hline Absent & $50(82.0)$ & $50(84.7)$ & $52(86.7)$ & 52 (86.7) & $204(85.0)$ \\
\hline
\end{tabular}

\section{LPV/r: lopinavir-ritonavir}


Table 3. Primary outcome analysis: SARS-CoV-2 viral load at Day 5 adjusted for baseline viral load

\begin{tabular}{|c|c|c|c|c|c|c|c|}
\hline & \multirow{2}{*}{$\mathbf{N}$} & \multicolumn{2}{|c|}{$\begin{array}{l}\text { Favipiravir+Placebo } \\
\text { (Main effect) }\end{array}$} & \multicolumn{2}{|c|}{$\begin{array}{l}\text { LPV/r+Placebo } \\
\text { (Main effect) }\end{array}$} & \multicolumn{2}{|c|}{$\begin{array}{l}\text { Interaction } \\
\text { Favipiravir+LPV/r }\end{array}$} \\
\hline & & $\begin{array}{l}\text { Coefficient } \\
(95 \% \mathrm{Cl})\end{array}$ & p-value & $\begin{array}{l}\text { Coefficient } \\
(95 \% \mathrm{Cl})\end{array}$ & p-value & $\begin{array}{l}\text { Coefficient } \\
(95 \% \mathrm{Cl})\end{array}$ & p-value \\
\hline \multicolumn{8}{|l|}{ Primary outcome } \\
\hline ITT population & 224 & $\begin{array}{c}-0.57 \\
(-1.21,0.07)\end{array}$ & 0.08 & $\begin{array}{c}-0.18 \\
(-0.82,0.46)\end{array}$ & 0.58 & $\begin{array}{c}0.59 \\
(-0.32,1.50) \\
\end{array}$ & 0.20 \\
\hline Modified ITT population & 208 & $\begin{array}{c}-0.59 \\
(-1.29,0.11) \\
\end{array}$ & 0.10 & $\begin{array}{c}-0.18 \\
(-0.87,0.51)\end{array}$ & 0.61 & $\begin{array}{c}0.65 \\
(-0.33,1.63) \\
\end{array}$ & 0.19 \\
\hline \multicolumn{8}{|l|}{ Adjusted analyses of primary outcome } \\
\hline Adjusted for minimisation factors & 224 & $\begin{array}{c}-0.57 \\
(-1.16,0.02)\end{array}$ & 0.06 & $\begin{array}{c}-0.14 \\
(-0.73,0.45)\end{array}$ & 0.65 & $\begin{array}{c}0.62 \\
(-0.22,1.46)\end{array}$ & 0.15 \\
\hline $\begin{array}{l}\text { Adjusted for minimisation factors, } \\
\text { symptom duration, antibody status }\end{array}$ & 222 & $\begin{array}{c}-0.65(-1.23,- \\
0.07) \\
\end{array}$ & 0.03 & $-0.09(-0.66,0.49)$ & 0.76 & $0.66(-0.16,1.48)$ & 0.11 \\
\hline \multicolumn{8}{|l|}{ Mixed model analysis - At day 5} \\
\hline ITT population & 235 & $\begin{array}{c}-0.57(-1.14 \\
0.01)\end{array}$ & 0.05 & $-0.24(-0.81,0.34)$ & 0.43 & $0.65(-0.17,1.47)$ & 0.12 \\
\hline $\begin{array}{l}\text { Adjusted for minimisation factors, } \\
\text { symptom duration, antibody status }\end{array}$ & 233 & $\begin{array}{c}-0.63(-1.17,- \\
0.08)\end{array}$ & 0.02 & $-0.15(-0.69,0.40)$ & 0.60 & $0.65(-0.11,1.42)$ & 0.10 \\
\hline
\end{tabular}

LPV/r: lopinavir-ritonavir 
Table 4. Odds ratios of achieving undetectable viral load ( $\mathrm{Ct} \geq 40$ ) by Day 5

\begin{tabular}{|c|c|c|c|c|c|c|c|c|c|c|c|}
\hline & \multirow[t]{2}{*}{$\begin{array}{c}\text { Sample } \\
\text { size* }\end{array}$} & \multirow{2}{*}{$\begin{array}{c}\text { Placebo } \\
\mathrm{N}(\%)\end{array}$} & \multicolumn{3}{|c|}{$\begin{array}{c}\text { Favipiravir+ Placebo } \\
\text { (Main effect) }\end{array}$} & \multicolumn{3}{|c|}{$\begin{array}{c}\text { LPV/r+Placebo } \\
\text { (Main effect) }\end{array}$} & \multicolumn{3}{|c|}{$\begin{array}{c}\text { Interaction } \\
\text { Favipiravir+LPV/r }\end{array}$} \\
\hline & & & $\mathrm{N}(\%)$ & $\begin{array}{c}\text { OR } \\
(95 \% \mathrm{Cl})\end{array}$ & p-value & $\mathrm{N}(\%)$ & $\begin{array}{c}\text { OR } \\
(95 \% \mathrm{Cl})\end{array}$ & p-value & $\mathrm{N}(\%)$ & $\begin{array}{c}\text { OR } \\
(95 \% \mathrm{Cl})\end{array}$ & $p$-value \\
\hline Undetectable viral load & 203 & $\begin{array}{c}14 \\
(26.9)\end{array}$ & $\begin{array}{c}25 \\
(46.3)\end{array}$ & $\begin{array}{c}2.47 \\
(1.08,5.65)\end{array}$ & 0.03 & $\begin{array}{c}17 \\
(30.4)\end{array}$ & $\begin{array}{c}1.29 \\
(0.55,3.00)\end{array}$ & 0.56 & $\begin{array}{c}20 \\
(35.7)\end{array}$ & $\begin{array}{c}0.52 \\
(0.16,1.66)\end{array}$ & 0.27 \\
\hline
\end{tabular}

* Patients included in this analysis had a detectable viral load at baseline and saliva sample available at Day 5.

LPV/r: lopinavir-ritonavir 
Table 5. Subgroup analyses for primary outcome according to vaccination status, duration of symptoms, baseline antibody status and baseline viral load.

\begin{tabular}{|c|c|c|c|c|c|c|c|c|c|c|c|}
\hline & \multirow{2}{*}{$\mathbf{N}$} & \multirow{2}{*}{$\begin{array}{c}\text { Placebo } \\
\text { N }\end{array}$} & \multicolumn{3}{|c|}{$\begin{array}{l}\text { Favipiravir+Placebo } \\
\text { (Main effect) }\end{array}$} & \multicolumn{3}{|c|}{$\begin{array}{l}\text { LPV/r+Placebo } \\
\text { (Main effect) }\end{array}$} & \multicolumn{3}{|c|}{$\begin{array}{c}\text { Interaction } \\
\text { Favipiravir+LPV/r }\end{array}$} \\
\hline & & & $\mathrm{N}$ & $\begin{array}{l}\text { Coefficient } \\
(95 \% \mathrm{Cl})\end{array}$ & $\begin{array}{l}\text { Interaction } \\
\text { p-value }\end{array}$ & N & $\begin{array}{l}\text { Coefficient } \\
(95 \% \mathrm{Cl})\end{array}$ & $\begin{array}{l}\text { Interaction } \\
p \text {-value }\end{array}$ & N & $\begin{array}{l}\text { Coefficient } \\
(95 \% \mathrm{Cl})\end{array}$ & $\begin{array}{c}\text { Interaction } \\
\text { p-value }\end{array}$ \\
\hline \multicolumn{12}{|l|}{ Vaccinated } \\
\hline Yes & 117 & 29 & 28 & $-0.71(-1.66,0.24)$ & \multirow{2}{*}{0.67} & 29 & $0.15(-0.79,1.09)$ & \multirow{2}{*}{0.32} & 31 & $0.90(-0.43,2.23)$ & \multirow{2}{*}{0.57} \\
\hline No & 107 & 29 & 28 & $-0.41(-1.09,0.27)$ & & 26 & $-0.45(-1.14,0.24)$ & & 24 & $0.36(-0.64,1.35)$ & \\
\hline \multicolumn{12}{|c|}{ Days from symptom onset } \\
\hline$\leq 5$ days & 148 & 35 & 38 & $-0.37(-1.17,0.44)$ & \multirow{2}{*}{0.55} & 35 & $0.02(-0.79,0.84)$ & \multirow{2}{*}{0.50} & 40 & $0.48(-0.65,1.61)$ & \multirow{2}{*}{0.93} \\
\hline$>5$ days & 75 & 22 & 18 & $-0.80(-1.86,0.26)$ & & 20 & $-0.43(-1.46,0.60)$ & & 15 & $0.42(-1.13,1.97)$ & \\
\hline \multicolumn{12}{|c|}{ Baseline antibody status } \\
\hline Negative & 80 & 23 & 20 & $-0.06(-0.75,0.63)$ & \multirow{2}{*}{0.27} & 20 & $-0.13(-0.81,0.55)$ & \multirow{2}{*}{0.98} & 17 & $-0.09(-1.10,0.91)$ & \multirow{2}{*}{0.24} \\
\hline Positive & 143 & 35 & 35 & $-0.86(-1.72,-0.01)$ & & 35 & $-0.14(-1.0,0.72)$ & & 38 & $1.08(-0.11,2.28)$ & \\
\hline \multicolumn{12}{|l|}{ Baseline viral load } \\
\hline$\leq$ Median viral load & 117 & 27 & 36 & $0.12(-0.72,0.96)$ & \multirow{2}{*}{0.03} & 35 & $-0.20(-1.11,0.70)$ & \multirow{2}{*}{0.94} & 29 & $0.09(-1.13,1.31)$ & \multirow{2}{*}{0.17} \\
\hline >Median viral load & 107 & 31 & 20 & $-1.30(-2.29,-0.30)$ & & 30 & $-0.13(-1.01,0.76)$ & & 26 & $1.28(-0.09,2.65)$ & \\
\hline
\end{tabular}

LPV/r: lopinavir-ritonavir 
Supplementary Table 1. Summary of adverse events.

\begin{tabular}{|c|c|c|c|c|c|}
\hline & $\begin{array}{l}\text { Favipiravir+LPV/r } \\
(\mathrm{N}=61)\end{array}$ & $\begin{array}{l}\text { Favipiravir+Placebo } \\
(\mathrm{N}=59)\end{array}$ & $\begin{array}{l}\text { LPV/r+Placebo } \\
(\mathrm{N}=60)\end{array}$ & $\begin{array}{l}\text { Placebo } \\
(\mathrm{N}=60)\end{array}$ & $\begin{array}{l}\text { Total } \\
(\mathrm{N}=240)\end{array}$ \\
\hline $\begin{array}{l}\text { Number of Patients reporting at least } 1 \mathrm{AE} ; \mathrm{N} \\
\text { (\%) }\end{array}$ & $55(90.1)$ & $38(64.4)$ & $59(98.3)$ & $\begin{array}{l}39 \\
(65.0)\end{array}$ & $191(80.0)$ \\
\hline Patients with at least one related event & $53(87.9)$ & $27(45.8)$ & $56(93.3)$ & $\begin{array}{l}21 \\
(35.0)\end{array}$ & $157(65.4)$ \\
\hline Number of AEs & 159 & 92 & 175 & 92 & 518 \\
\hline Related events & $108(67.9)$ & $44(47.3)$ & $116(65.9)$ & $\begin{array}{l}27 \\
(29.3)\end{array}$ & $295(56.7)$ \\
\hline \multicolumn{6}{|l|}{ AE Event [\# events] } \\
\hline Diarrhoea & 41 & 8 & 47 & 10 & 106 \\
\hline Nausea & 16 & 13 & 28 & 6 & 63 \\
\hline Dyspnea & 5 & 6 & 7 & 6 & 24 \\
\hline Headache & 6 & 7 & 4 & 6 & 23 \\
\hline Anosmia & 5 & 3 & 9 & 5 & 22 \\
\hline Fatigue & 4 & 4 & 7 & 7 & 22 \\
\hline Vomiting & 8 & 1 & 6 & 2 & 17 \\
\hline Cough & 2 & 5 & 4 & 5 & 16 \\
\hline Dysgeusia & 3 & 4 & 6 & 3 & 16 \\
\hline Abdominal pain & 2 & 3 & 2 & 5 & 12 \\
\hline Anorexia & 2 & 1 & 7 & 2 & 12 \\
\hline Dizziness & 4 & 1 & 6 & 0 & 11 \\
\hline Alanine aminotransferase increased & 6 & 1 & 1 & 1 & 9 \\
\hline
\end{tabular}




\begin{tabular}{|l|l|l|l|l|l|}
\hline Myalgia & 3 & 2 & 1 & 3 & 9 \\
\hline Rash maculo-papular & 2 & 4 & 1 & 2 & 9 \\
\hline Aspartate aminotransferase increased & 4 & 0 & 1 & 2 & 7 \\
\hline Nasal congestion & 1 & 3 & 1 & 2 & 7 \\
\hline Non-cardiac chest pain & 4 & 0 & 1 & 2 & 7 \\
\hline Hyperuricemia & 0 & 2 & 0 & 0 & 2 \\
\hline
\end{tabular}

LPV/r: lopinavir-ritonavir, AE: adverse event 
Supplementary Table 2. Serum liver function tests and uric acid at Day 1 and Day 7.

\begin{tabular}{|c|c|c|c|c|c|c|c|c|c|c|}
\hline & \multicolumn{2}{|c|}{$\begin{array}{l}\text { Favipiravir+LPV/r } \\
\quad(\mathrm{N}=61)\end{array}$} & \multicolumn{2}{|c|}{$\begin{array}{l}\text { Favipiravir+Placebo } \\
\qquad(\mathrm{N}=59)\end{array}$} & \multicolumn{2}{|c|}{$\begin{array}{l}\text { LPV/r+Placebo } \\
(\mathrm{N}=60)\end{array}$} & \multicolumn{2}{|l|}{$\begin{array}{c}\text { Placebo } \\
(\mathrm{N}=60)\end{array}$} & \multicolumn{2}{|l|}{$\begin{array}{c}\text { Total } \\
(\mathrm{N}=\mathbf{2 4 0})\end{array}$} \\
\hline & $\begin{array}{l}\text { median } \\
\text { (IQR) }\end{array}$ & $\begin{array}{c}\text { Outside } \\
\text { normal } \\
\text { range } \\
\mathrm{N}(\%)\end{array}$ & $\begin{array}{l}\text { median } \\
(\mathrm{IQR})\end{array}$ & $\begin{array}{c}\text { Outside } \\
\text { normal } \\
\text { range } \\
\mathrm{N}(\%)\end{array}$ & $\begin{array}{l}\text { median } \\
(\mathrm{IQR})\end{array}$ & $\begin{array}{c}\text { Outside } \\
\text { normal } \\
\text { range } \\
\mathrm{N}(\%)\end{array}$ & $\begin{array}{l}\text { median } \\
(\mathrm{IQR})\end{array}$ & $\begin{array}{c}\text { Outside } \\
\text { normal } \\
\text { range } \\
\mathrm{N}(\%) \\
\end{array}$ & $\begin{array}{l}\text { median } \\
(\mathrm{IQR})\end{array}$ & 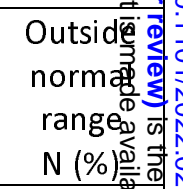 \\
\hline \multicolumn{11}{|c|}{ ALT (IU/L) } \\
\hline Day 1 & $27.0(19.0-41.0)$ & $18(30.0)$ & $28.0(20.0-45.0)$ & $15(25.9)$ & $24.0(15.0-36.5)$ & $10(16.9)$ & $24.5(15.0-38.5)$ & $15(25.0)$ & $26.0(16.0-41.0)$ & $58(24.6)$ \\
\hline Day 7 & $27.0(18.0-37.0)$ & $15(25.0)$ & $35.5(24.5-50.5)$ & $22(37.9)$ & $21.0(15.0-28.0)$ & $4(6.8)$ & $22.5(17.5-36.0)$ & $13(21.7)$ & $26.0(18.0-38.5)$ & $54(22.8)$ \\
\hline Change & $-2.0(-12.0-6.0)$ & & $1.0(-3.0-12.0)$ & & $-2.0(-8.0-1.0)$ & & $0.0(-4.5-5.0)$ & & $-1.0(-7.0-5.0)$ & \\
\hline \multicolumn{11}{|c|}{ AST (IU/L) } \\
\hline Day 1 & $32.0(28.0-41.0)$ & $18(30.0)$ & $34.0(28.0-43.0)$ & $19(32.8)$ & $31.0(27.0-36.5)$ & $12(20.3)$ & $30.5(26.0-36.5)$ & $16(26.7)$ & $32.0(27.0-38.0)$ & 65 (27. 然o \\
\hline Day 7 & $28.0(25.0-34.0)$ & $13(21.7)$ & $32.5(28.0-39.5)$ & $15(25.9)$ & $28.0(25.0-31.0)$ & $3(5.1)$ & $28.0(24.0-32.5)$ & $9(15.0)$ & $29.0(25.0-34.0)$ & 40 (16.9) \\
\hline Change & $-3.0(-8.0-1.0)$ & & $-2.0(-6.0-3.0)$ & & $-2.0(-6.0-0.0)$ & & $-1.5(-5.0-1.5)$ & & $-2.0(-7.0-2.0)$ & \\
\hline \multicolumn{11}{|c|}{ ALP (IU/L) } \\
\hline Day 1 & $60.0(53.0-74.0)$ & $1(1.7)$ & $60.5(54.0-70.0)$ & $0(0.0)$ & $57.5(49.0-72.5)$ & $0(0.0)$ & $60.5(52.0-72.5)$ & $1(1.7)$ & $60.0(52.0-72.0)$ & $2(0.88$ \\
\hline Day 7 & $67.0(57.0-83.0)$ & $2(3.3)$ & $66.0(58.5-77.0)$ & $1(1.7)$ & $60.0(51.0-76.0)$ & $1(1.7)$ & $66.0(54.5-77.0)$ & $1(1.7)$ & $65.0(55.0-78.0)$ & $5(2.1 \bar{\delta}$ \\
\hline Change & $4.0(1.0-12.0)$ & & $6.0(2.0-13.0)$ & & $2.0(-2.0-6.0)$ & & $1.5(-1.0-8.0)$ & & $4.0(0.0-10.0)$ & \\
\hline \multicolumn{11}{|c|}{ Bilirubin $(\mu \mathrm{mol} / \mathrm{L})$} \\
\hline Day 1 & $5.0(4.0-8.0)$ & $1(1.7)$ & $6.0(4.0-8.0)$ & $1(1.7)$ & $6.0(3.0-7.0)$ & $0(0.0)$ & $7.0(4.0-9.0)$ & $0(0.0)$ & $6.0(4.0-8.0)$ & $2(0.8) \frac{\bar{c}}{g}$ \\
\hline Day 7 & $10.0(6.0-14.0)$ & $2(3.3)$ & $6.0(4.0-9.0)$ & $1(1.7)$ & $8.5(6.0-13.0)$ & $4(6.8)$ & $7.0(5.0-10.0)$ & $1(1.7)$ & $8.0(5.0-12.0)$ & $8(3.4) \equiv$ \\
\hline Change & $4.0(1.0-8.0)$ & & $1.0(-1.0-3.0)$ & & $4.5(0.0-8.5)$ & & $2.0(-2.0-3.0)$ & & $2.0(0.0-5.0)$ & \\
\hline \multicolumn{11}{|c|}{ Uric acid $(\mu \mathrm{mol} / \mathrm{L})$} \\
\hline Day 1 & $275.0(209.0-336.0)$ & $7(11.5)$ & $253.0(216.0-315.0)$ & $5(8.5)$ & 256.5 (196.0-297.5) & $6(10.0)$ & $285.0(210.5-327.0)$ & $5(8.3)$ & $265.0(209.0-320.0)$ & $23(9.6)$ \\
\hline
\end{tabular}




\begin{tabular}{|l|c|c|c|c|c|c|c|c|c|c|}
\hline Day 7 & $369.5(299.0-441.0)$ & $18(29.5)$ & $422.5(349.5-498.0)$ & $22(37.3)$ & $258.5(203.5-316.0)$ & $5(8.3)$ & $275.5(238.5-346.0)$ & $2(3.3)$ & $329.0(251.0-401.0)$ & $47(19.6)$ \\
\hline Day 14 & $306.0(265.0-400.0)$ & $2(8.0)$ & $329.0(287.0-354.0)$ & $1(3.7)$ & $288.5(247.5-331.5)$ & $1(5.0)$ & $310.0(237.0-353.0)$ & $2(9.1)$ & $303.5(250.0-253.0)$ & $6(6.4)$ \\
\hline Change & $-2.0(-12.0-6.0)$ & & $1.0(-3.0-12.0)$ & & $-2.0(-8.0-1.0)$ & & $0.0(-4.5-5.0)$ & & $-1.0(-7.0-5.0)$ & \\
\hline
\end{tabular}

LPV-r: lopinavir/ritonavir, ALT: alanine aminotransferase, AST: aspartate aminotransferase, ALP: alkaline phosphatase, IU: international units, $\mu$ mol: micromoles 
Supplementary Table 3. Baseline characteristics of the cohort with pharmacokinetic measurements.

\begin{tabular}{|l|l|c|c|}
\hline $\begin{array}{l}\text { Characteristics of Pk } \\
\text { group at screening }\end{array}$ & \multicolumn{1}{|c|}{$\begin{array}{c}\text { Favipiravir+LPV/r } \\
\text { (N=28) }\end{array}$} & $\begin{array}{c}\text { Favipiravir+Placebo } \\
\text { (N=31) }\end{array}$ \\
\hline Age (years) & mean (sd) & $39.4(13.4)$ & $40.9(11.7)$ \\
\hline Gender & $\mathrm{N}(\%)$ & $16(57.1)$ & $17(54.8)$ \\
\hline Male & & $12(42.9)$ & $14(45.2)$ \\
\hline Female & & & $27(87.1)$ \\
\hline Ethnicity & $\mathrm{N}(\%)$ & $23(82.1)$ & $4(12.9)$ \\
\hline Caucasian & & $5(17.9)$ & \\
\hline Other & & & $49(83.1)$ \\
\hline BMI $\left(\mathrm{kg} / \mathrm{m}^{2}\right)$ & $\mathrm{N}(\%)$ & $23(82.1)$ & $5(16.1)$ \\
\hline$<30$ & & $5(17.9)$ & \\
\hline$\geq 30$ & & & \\
\cline { 2 - 4 }
\end{tabular}

LPV/r: lopinavir-ritonavir 
medRxiv preprint doi: https://doi.org/10.1101/2022.02.11.22270775; this version posted February 15, 2022. The copyright holder for this preprint (which was not certified by peer review) is the author/funder, who has granted medRxiv a license to display the preprint in perpetuity.

\author{
It is made available under a CC-BY-NC-ND 4.0 International license.
}




\section{Supplementary Appendix - FLARE Investigators}

Trial Steering Committee:

Kristina Nadrah (Chair), Robert C Read, Elizabeth Allen, Mahdia Sait

Independent Data Monitoring Committee:

Stephen Owens (Chair), David Chadwick, April Slee, Andrew Ustianowski

UCL Comprehensive Clinical Trials Unit:

Krishneya Anojan, Gemma Jones, Nazma Begum-Ali, Natasha Majid

Royal Free Hospital Clinical Trials team:

Rachel Ochiel, Debbie Falconer, Stella O'Connor, Karl Salazar, Tung Le, Francesca Gowing, Ivy

Wanjiku Dakouri, Tanaka Ngcozana, Sandra Lopez Garces, Karima Oduka, Daniel Jones, Eva Torok-

Pollok

University College London Hospital Clinical Trials team:

Michelle Berkeley, Esther King, Kimberlee Gunn

Great Ormond Street Hospital laboratories:

Francis Yongblah, Mabel Csatari, Kimberly Gilmour

Royal Free Hospital and UCL (Royal Free campus) laboratories:

Naseem Ahmed, Janki Kavi, Nimesha Patel, Hatim Ebrahim

University of Birmingham laboratories:

Alex Richter, Adrian Shields 


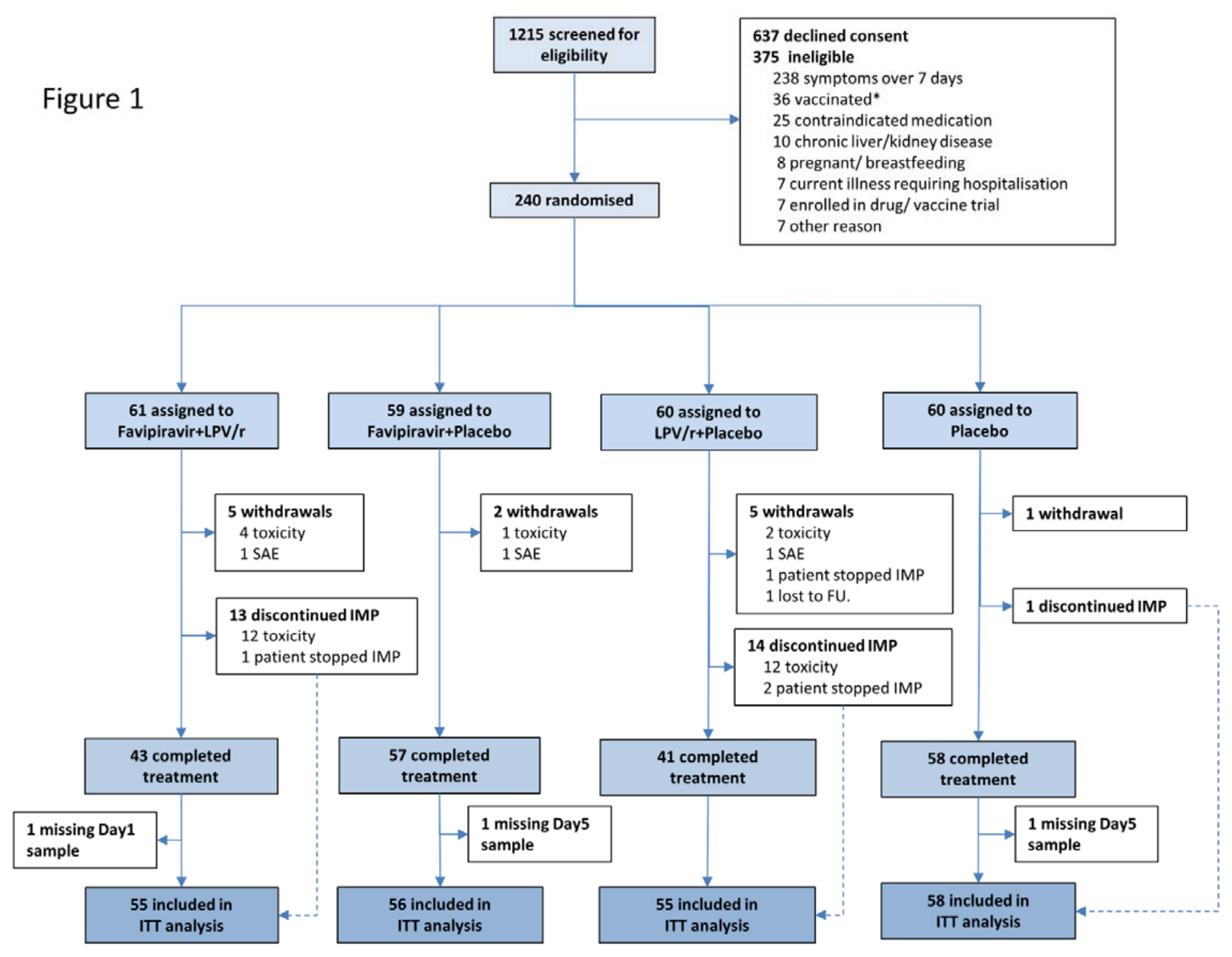


Figure 2

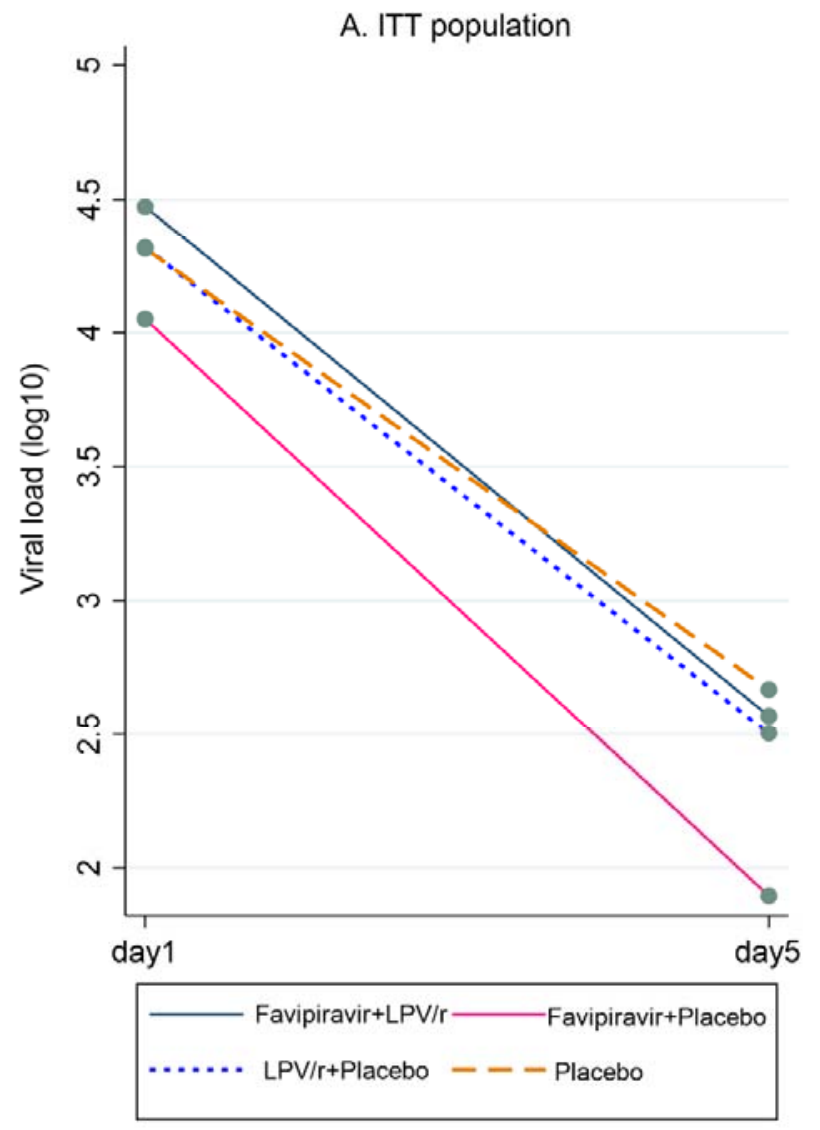

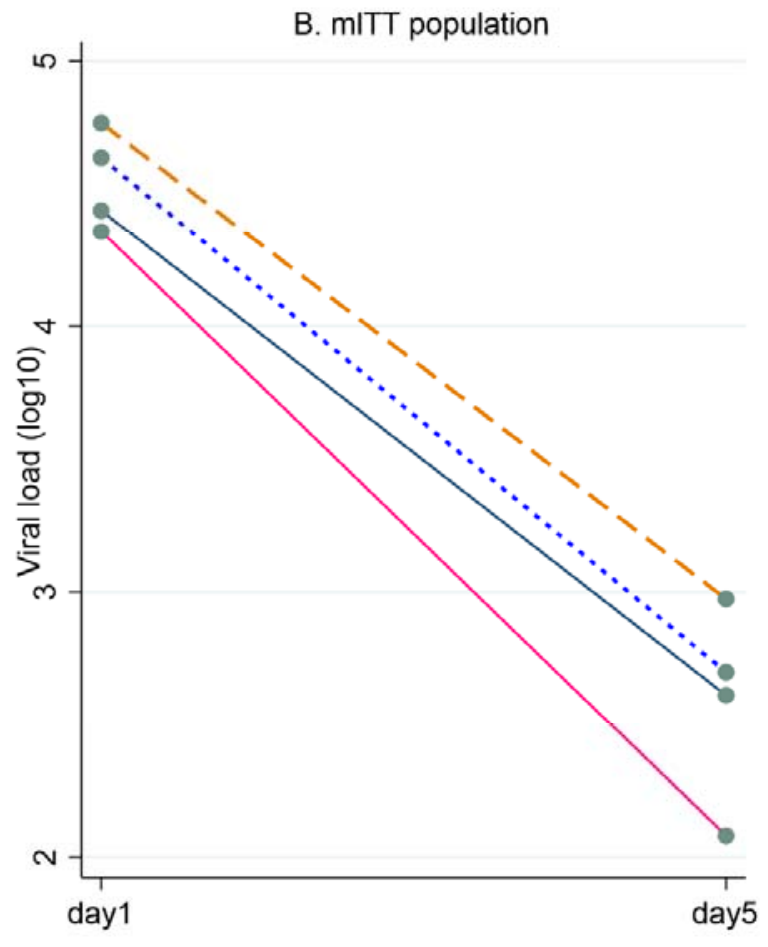

- Favipiravir $+\mathrm{LPV} / \mathrm{r}-$ Favipiravir+ Placebo
$\ldots \ldots . . \mathrm{LPV} / \mathrm{r}+$ Placebo --
-Placebo 
Figure 3

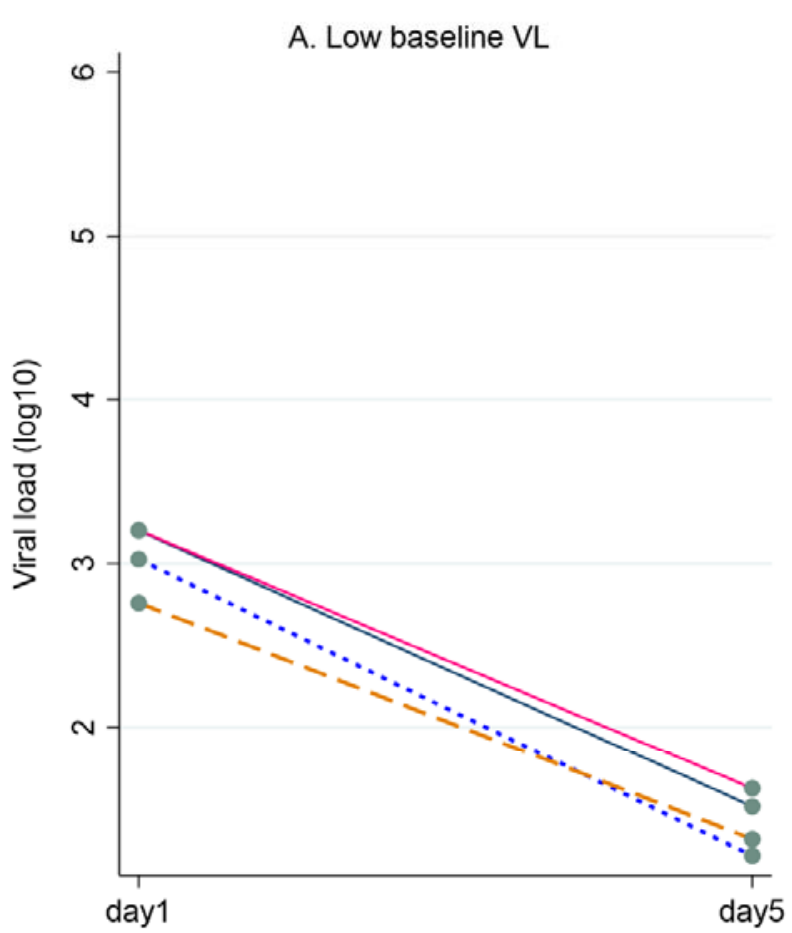

day1

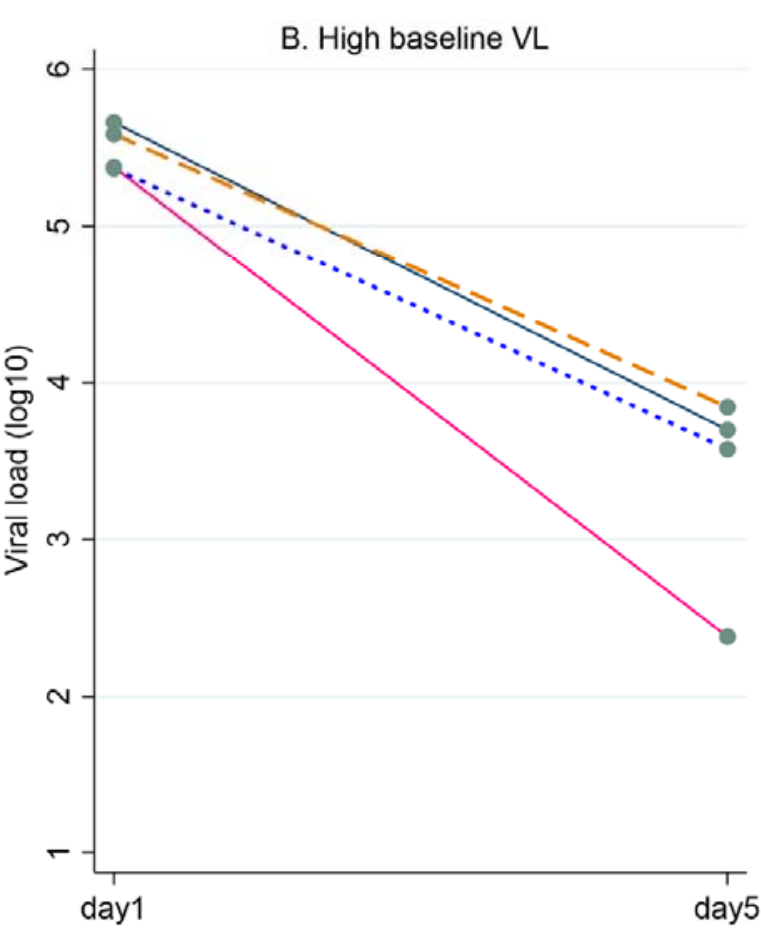

-Favipiravir+LPV/r — Favipiravir+Placebo

.......LPV/r+Placebo --- Placebo 
Figure 4

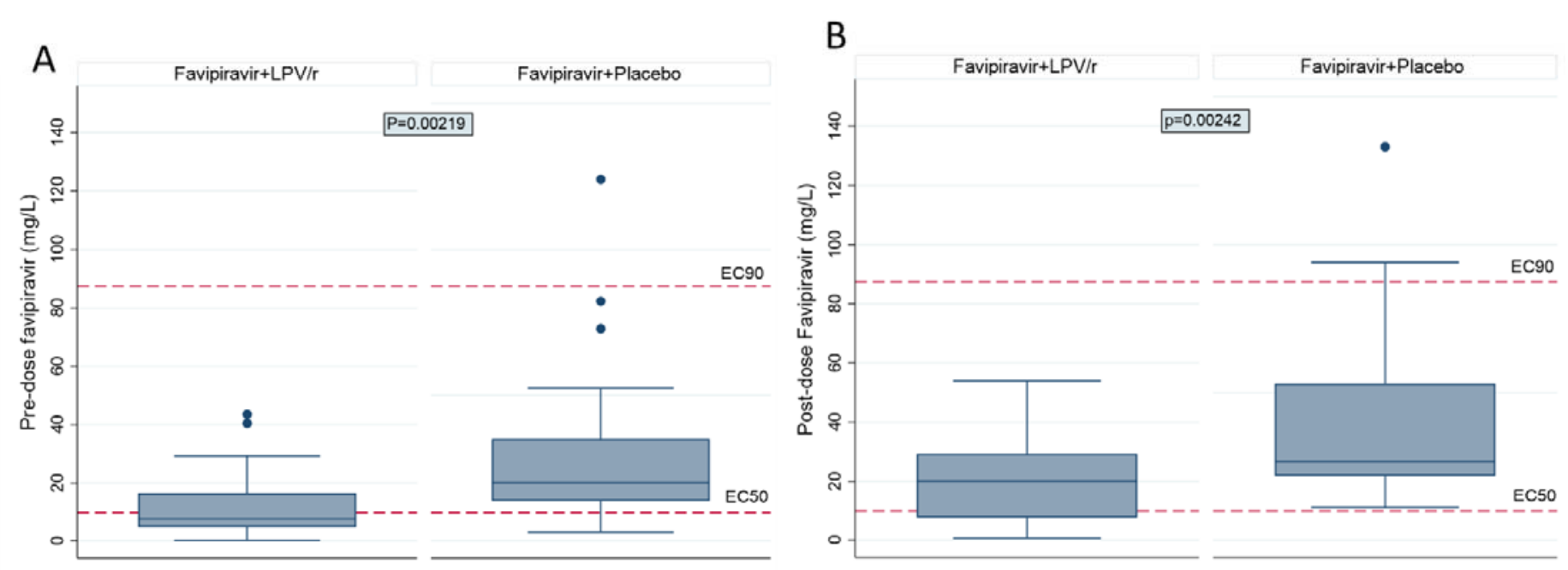




\section{Supplementary Figure 1}

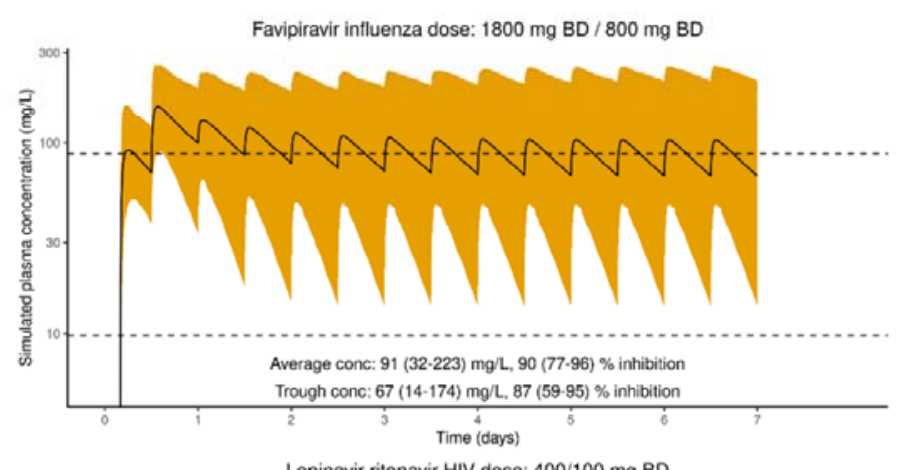

Lopinavir-ritonavir HIV dose: 400/100 mg BD

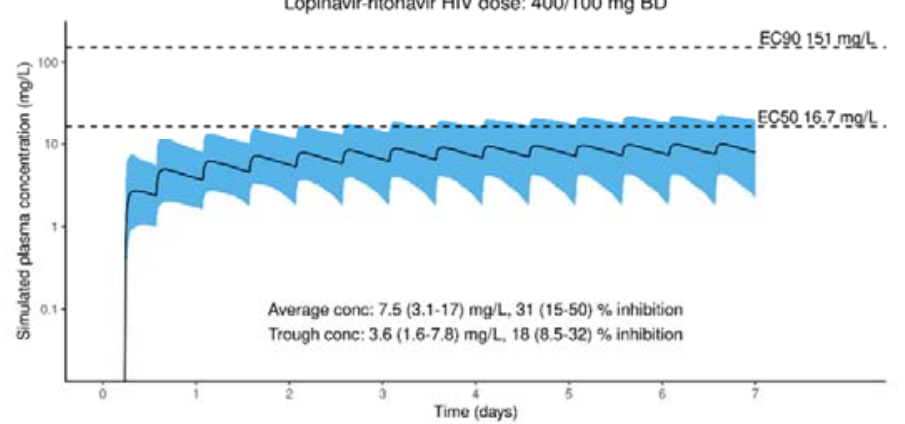

Favipiravir FLARE dose: $1800 \mathrm{mg}$ BD / $400 \mathrm{mg}$ QDS

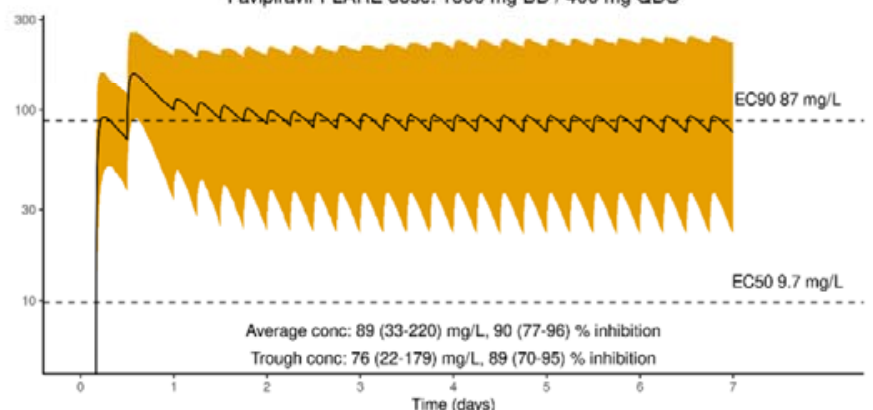

Lopinavir-ritonavir FLARE dose: $400 / 100 \mathrm{mg}$ BD / 200/50 mg QDS

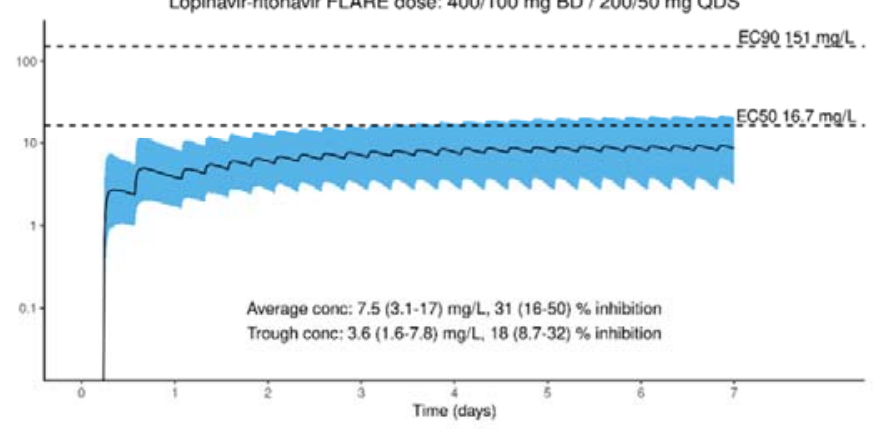




\section{Supplementary Figure 2}
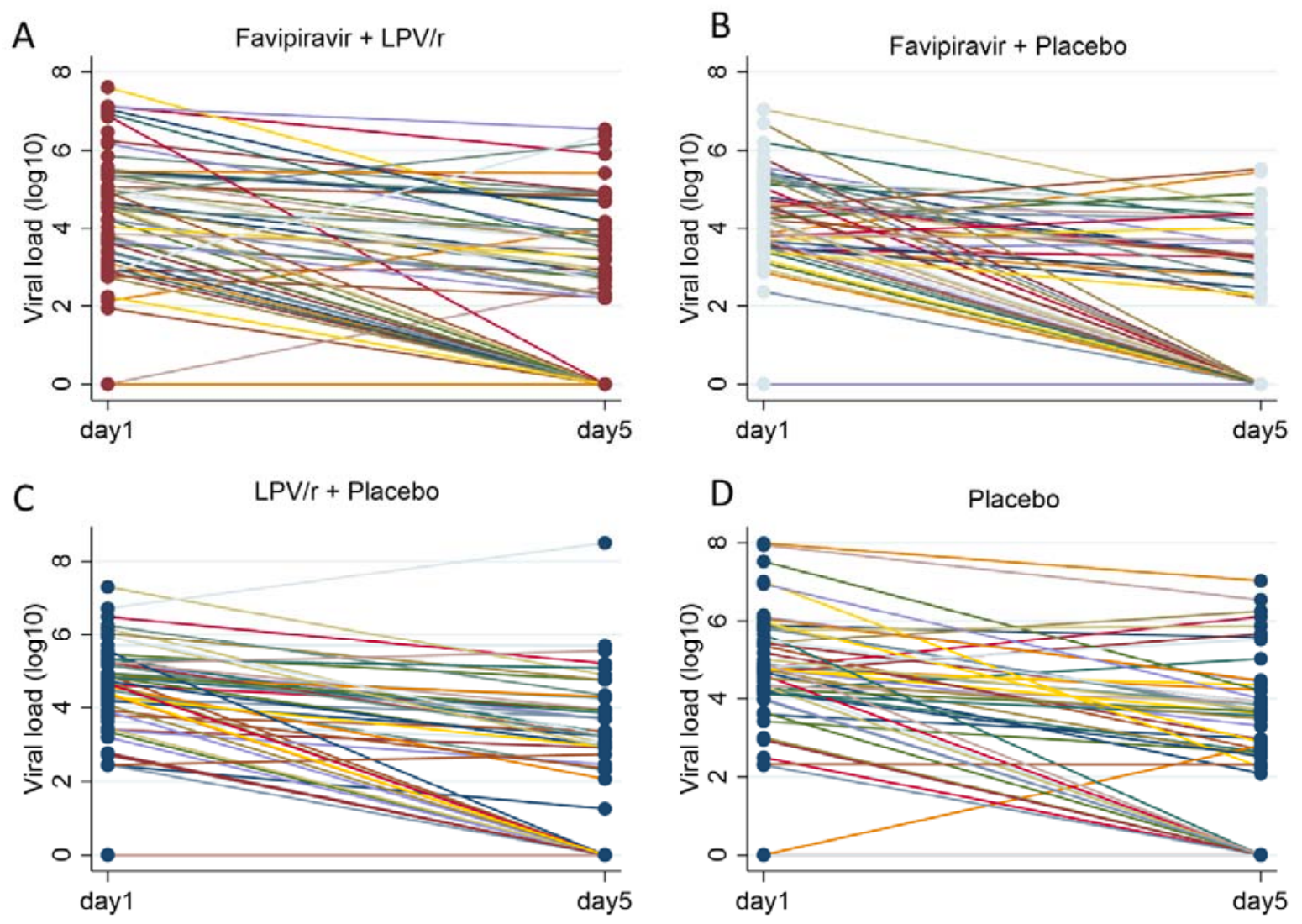


\section{Supplementary Figure 3}
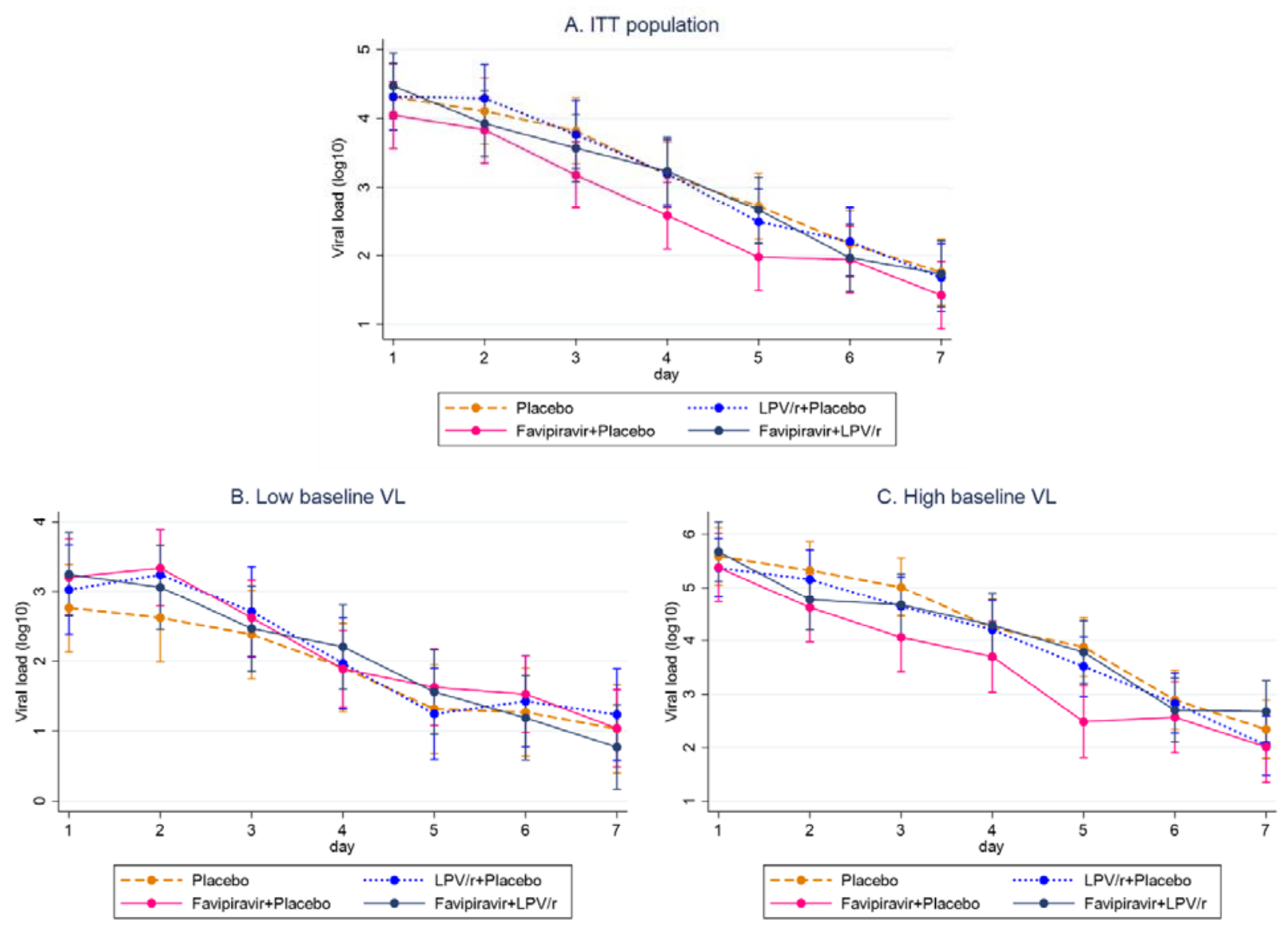


\section{Supplementary Figure 4}

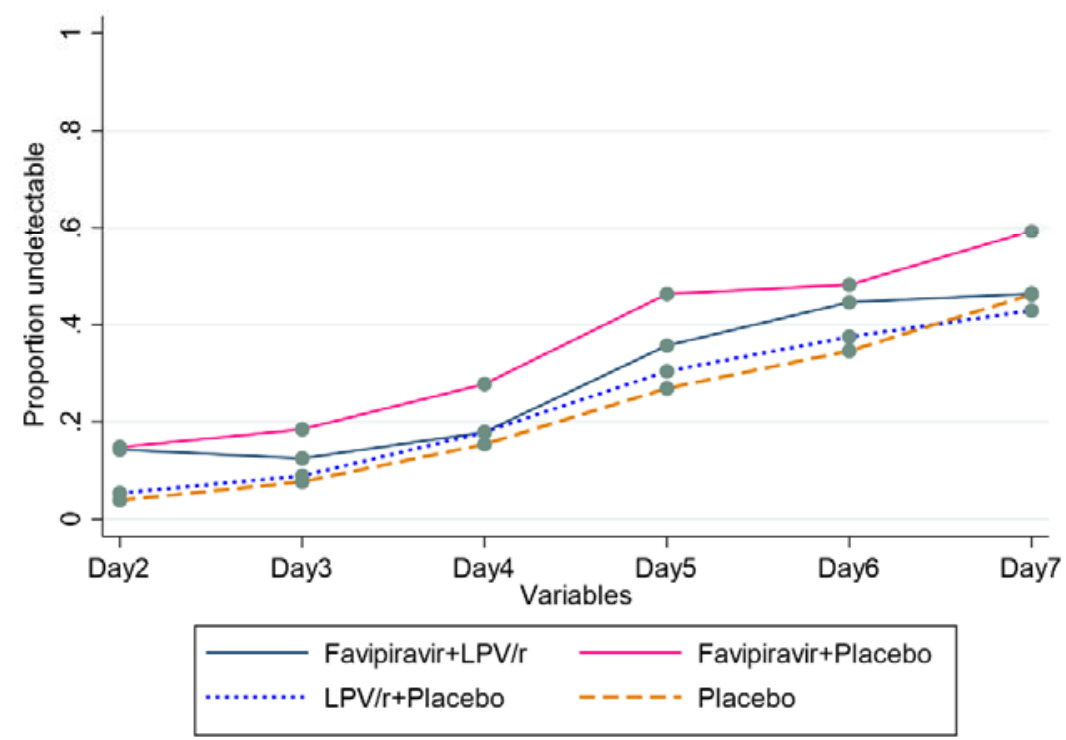

\begin{tabular}{|l|c|c|c|c|c|}
\hline Undetectable viral load & $\begin{array}{c}\text { Favipiravir+LPV/r } \\
(\mathbf{N = 5 6 )}\end{array}$ & $\begin{array}{c}\text { Favipiravir+Placebo } \\
(\mathbf{N}=54)\end{array}$ & $\begin{array}{c}\text { LPV/r+Placebo } \\
(\mathbf{N}=56)\end{array}$ & $\begin{array}{c}\text { Placebo } \\
(\mathbf{N}=52)\end{array}$ & $\begin{array}{c}\text { Total } \\
(\mathbf{N}=\mathbf{2 1 8})\end{array}$ \\
\hline Day 2 & $8(14.3)$ & $8(14.8)$ & $3(5.4)$ & $2(3.9)$ & $21(9.6)$ \\
\hline Day 3 & $7(12.5)$ & $10(18.5)$ & $5(8.9)$ & $4(7.7)$ & $26(11.9)$ \\
\hline Day 4 & $10(17.9)$ & $15(27.8)$ & $10(17.9)$ & $8(15.4)$ & $43(19.7)$ \\
\hline Day 5 & $20(35.7)$ & $25(46.3)$ & $17(30.4)$ & $14(26.9)$ & $76(34.9)$ \\
\hline Day 6 & $25(44.6)$ & $26(48.2)$ & $21(37.5)$ & $18(34.6)$ & $90(41.3)$ \\
\hline Day 7 & $26(46.4)$ & $32(59.3)$ & $24(42.9)$ & $24(46.2)$ & $106(48.6)$ \\
\hline
\end{tabular}


Supplementary Figure 5
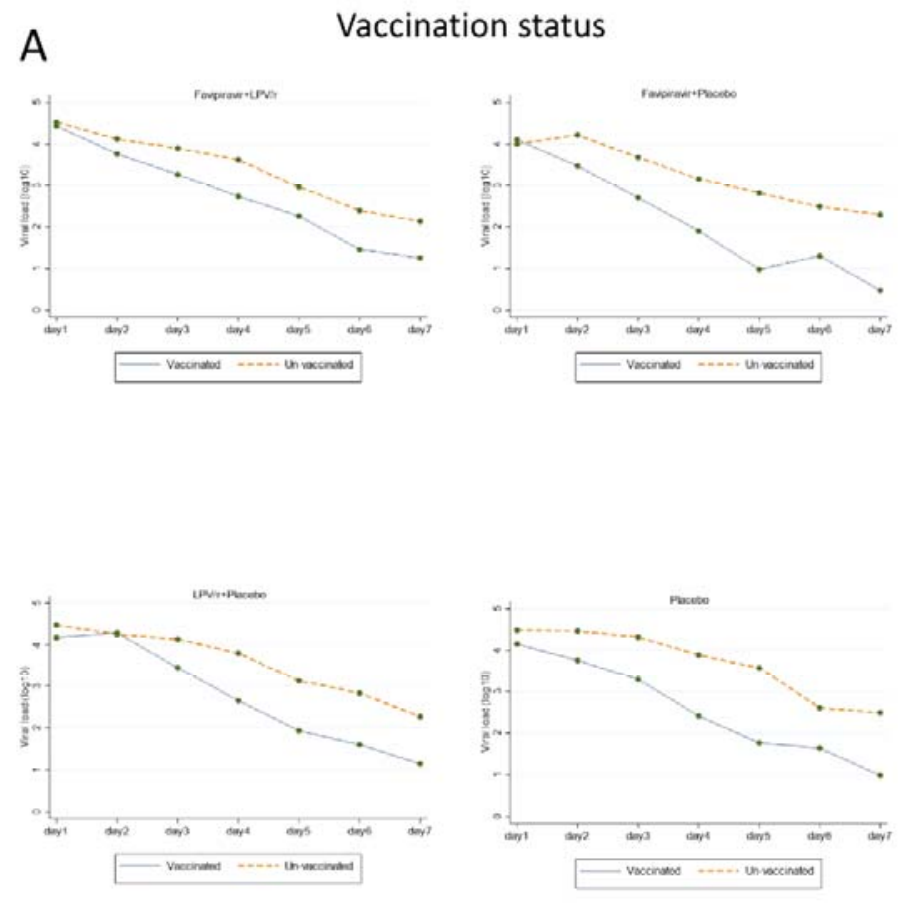

B
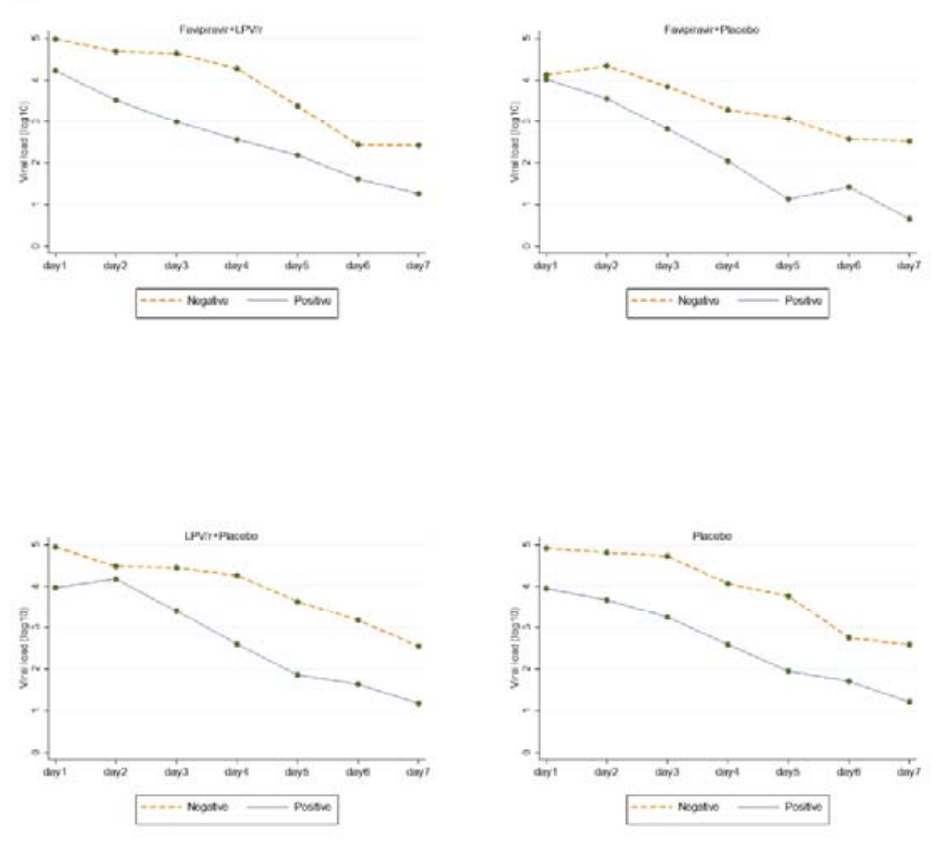

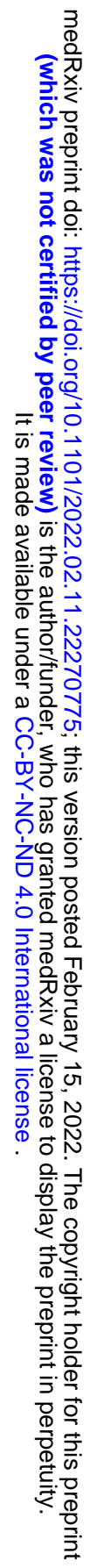


Supplementary Figure 6
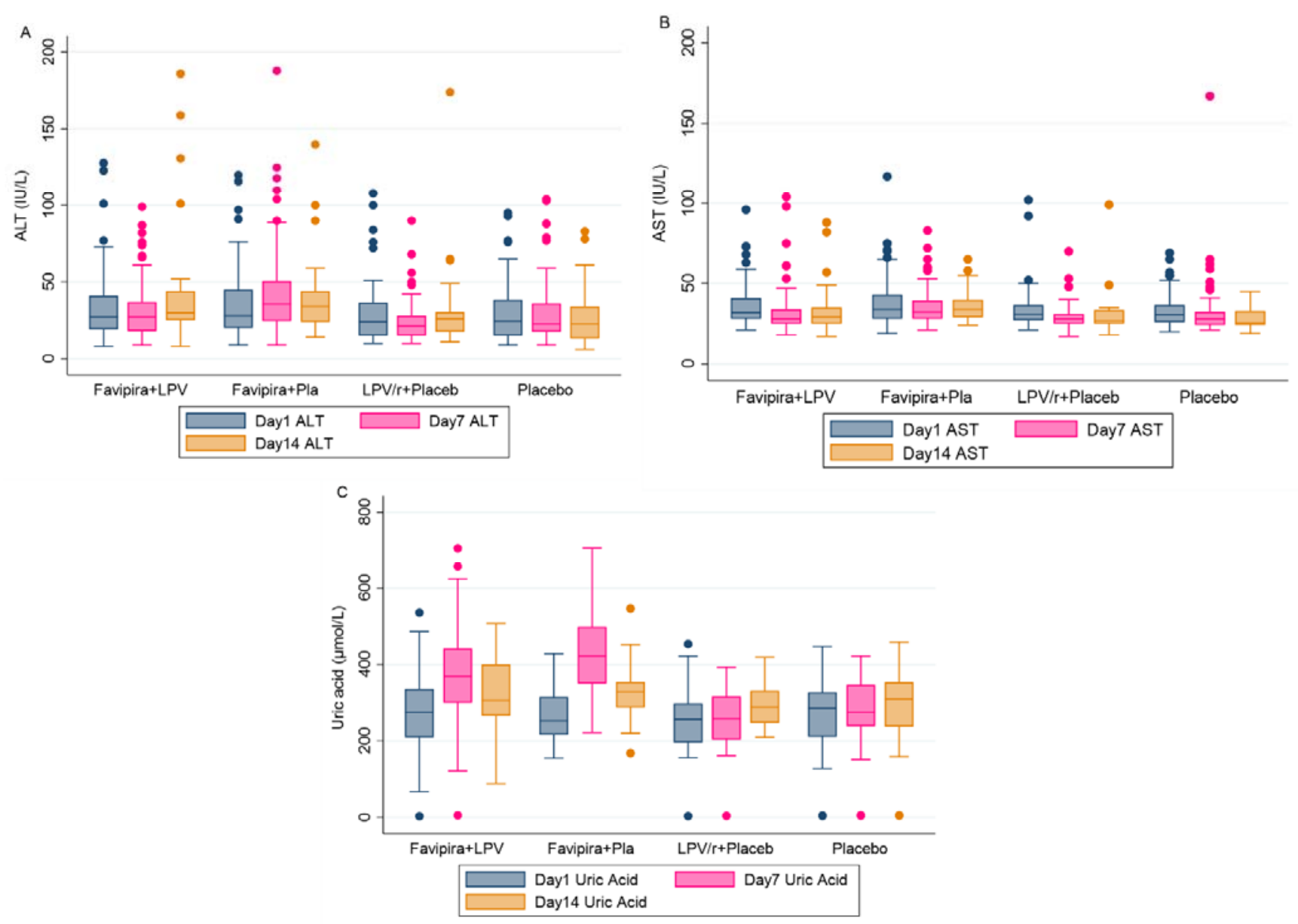